\title{
Legal Documents - Modernising the Formalities
}

\author{
Graham McBain $^{1,2}$ \\ ${ }^{1}$ Peterhouse, Cambridge, UK \\ ${ }^{2}$ Harvard Law School, USA \\ Correspondence: Graham McBain, 21 Millmead Terrace, Guildford, Surrey GU2 4AT, UK. E-mail: \\ gsmcbain@aol.com
}

Received: November 22, 2018 Accepted: December 11, 2018 Online Published: January12, 2019

doi:10.5539/ilr.v8n1p1

URL: https://doi.org/10.5539/ilr.v8n1p1

\section{INTRODUCTION ${ }^{1}$}

Today, we live in an electronic age. One which is far removed from medieval times when the English courts laid down various formalities that were required in order to make a legal document ${ }^{2}$ binding. The fact that a large majority of the population of England was, at the time of the Norman Conquest (1066), illiterate - indeed, incapable of even signing their name ${ }^{3}$ - resulted in the party (or parties) to a legal document executing it with a seal. ${ }^{4}$ This was the means by which the makers of a legal document confirmed themselves to be legally bound.

It was also from this period - from the time of Bracton (c.1250) onwards ${ }^{5}$ - that the English courts began to recognise a 'hierarchy' of legal documents, with some being accorded a higher evidential worth (probative value) than others, in the eyes of the court. Thus, in descending order, the hierarchy of legal documents was as follows, a:
(a) royal charter; ${ }^{6}$
(b) instrument of record; (i.e. a registered legal document); ${ }^{7}$
(c) deed $;^{8}$
(d) specialty; ${ }^{9}$

\footnotetext{
${ }^{1}$ See generally, the following by GS McBain: (a) Abolishing, Deeds, Specialties and Seals, Parts 1 \& 2 (2006) 20(1) Commercial Law Quarterly ('CLQ'), pp 15-54 and 20(2) CLQ, pp 3-28 ('McBain Deeds'); (b) Modernising the Law of Notarisation and Public Notaries [2016] Journal of Business Law ('JBL'), Issue 2, pp 91-114 ('McBain Notarisation'); (c) Abolishing the Statute of Frauds 1677, s 4 ('McBain Statute of Frauds') [2010] JBL, Issue 5, pp 420-43 (it deals with the requirement of a guarantee to be in writing); and (d) Abolishing the Doctrine of Consideration ('McBain Consideration') [2018] International Law Research, vol 7, no 1, pp 1-104. These articles contain extensive bibliographies. See also Halsbury, Laws of England ( $5^{\text {th }}$ ed) for these matters ('Halsbury'). For notarization, see G McBain, Modernising the Law on Notarisation and Public Notaries [2016] JBL 91-114 ('McBain Notaries').For notaries and notarization in Scotland in early times, see Ars Notariatus (Edinburgh, 1740).

${ }^{2}$ The old word for a legal document was an 'instrument'. McBain Deeds, n 1, pt 1, p 32, n 2. See also Halsbury, n 1, vol 32, para 339 and Law of Property Act 1925, s 205(1)(viii)('instrument'). In modern times, it would seem a good idea to refer to a 'legal document' since it is more in use than the word 'instrument.' See Oxford English Dictionary ('OED')(document). A legal document, then, can be defined as a reference to 'any writing intended to have legal effect.'

${ }^{3}$ In Anglo-Saxon times, legal documents were not signed with a signature. Nor sealed. However, kings (and clerics), sometimes, when making a legal document, put their mark on the parchment (usually, in the form of a cross), to authenticate it (i.e. to express their intention to be bound).

${ }^{4}$ There has never been any stipulation as to the type of seal required. Thus, it could be wax, a wafer (common after 1840) or an impression which could be made with a ruler or a stick or in the form of a circle or the acronym 'LS' (for lex sigilli). It could also be plain (no crest, initials or coat of arms was needed) or fanciful as well as any shape, size or colour. Today, it is common for there to be no seal at all - it being replaced by the word 'sealed' which is intended to create an estoppel.

${ }^{5} \mathrm{H}$ Bracton (trans Thorne), On the Law and Customs of England c.1240 (Cambridge UP, 1968-76). Bracton is online, see bracton.law.harvard.edu

${ }^{6}$ At first, any writing (carta, charter) authenticated by the king's seal was treated as conclusive. This principle was, later, extended to the records of the king's court. See also McBain Deeds, n 1, pt 1, pp 18, 36-7.

${ }^{7}$ R Glanvill, The Treatise on the Laws and Customs of the Realm of England (c. 1189)(Nelson, 1965), p 100 'it is necessary...to abide by their record and neither party may object to it.' See also $n 36$.

${ }^{8}$ In early times a deed comprised a legal document on parchment (paper did not arrive in England until the $14^{\text {th }}$ century) that was sealed and delivered. Any legal document on parchment that was sealed and delivered, ipso facto, was a deed. However, if the legal document was sealed but did not meet these requirements, then, it could be a specialty or a sealed legal document (an instrument under seal). Estoppel by deed grew out of estoppel by record.
} 
(e) instrument under seal (i.e. a sealed legal document); ${ }^{10}$

(f) instrument under hand (i.e. a signed legal document) ${ }^{11}$

(g) parol (i.e. oral, verbal) declaration (unilateral) or agreement (bilateral). ${ }^{12}$

The courts also, sometimes, interpreted the above differently. ${ }^{13}$ Today, things have changed greatly. The vast majority of people in England and Wales are both literate and capable of signing their name. Also, the electronic signature is now an important means of executing a legal document and, doubtless, such will greatly increase. This article argues, therefore, that the above hierarchy of formalities is obsolete and that it should be dispensed with by also dispensing with certain legal forms that are wholly out of sync with modern social and commercial realities. In particular, the legal concepts of a deed and a specialty should be abolished, as well as the practice of sealing. ${ }^{14}$ These forms of executing a legal document nowadays are wholly unnecessary, since everyone, generally, signs - both natural and legal persons. ${ }^{15}$ Thus, the voluminous, confused ${ }^{16}$ and complex law on deeds, specialties and seals should be placed in the legal dustbin. There are other formalities beside these, the absence of which may invalidate an otherwise binding legal document. Such comprise the following:

- notarisation;

- legalisation (consularisation, appostillization);

- $\quad$ attestation (i.e. a witness signing when present at the execution of the legal document);

- witnessing.

Currently, there is uncertainty when the above are required at common law. Given this, any requirement for the same should be abolished at common law and legislation should now regulate such things. Further, the noting and protest of any foreign bill of exchange (which involves the notarisation of the same) should also be abolished. ${ }^{17}$ Further, any statutory requirement to attest a legal document should be abolished. And, any statutory requirement to witness a legal document should only be required in a reduced set of circumstances. Finally, English law requires - for some legal acts - is that they must be in writing, to be valid. Any such common law requirement for writing should be abolished and legislation should now regulate this. Also - in the case of a guarantee - the statutory requirement of writing (or evidence of such) should be abolished. ${ }^{18}$

In conclusion, the law needs a Formalities Act. ${ }^{19}$ One which sets out, very simply, the formal requirements in order for a legal document (i.e. one intended to have legal effect) to be legally valid. One which also recognises the ubiquity of the signature (including the electronic signature). One which reduces formal requirements to a minimum - so that an otherwise valid legal document is not invalidated without very good reason.

\footnotetext{
${ }^{9}$ The concept of a 'specialty' has always been confused, often, being taken to be a reference to a type of deed (one evidencing a debt). However, it has also been used to cover deeds and other sealed legal documents. Likely, it was a separate legal concept covering, for example, a sealed tally which was not treated as a deed, not being sufficiently permanent, see 4. For the full hierarchy of written and nonwritten acts of evidential worth in early times (including the handshake etc), see McBain Consideration, n 1, pt 1, pp 67-8.

${ }^{10}$ A deed not delivered was merely a sealed legal document (an instrument under seal). So too, were other legal documents under seal such as an award, a sub-poena, letter of ordination etc, see 4.

${ }^{11}$ Until the time of Henry VIII (1509-47) people did not generally sign (write their signature) on documents. However, with the great expansion of credit in the $17^{\text {th }}$ century, legal documents such as bills of exchange and promissory notes, were signed as opposed to being sealed. These had to be tried and determined by a jury, being treated as debts by way of simple contract. See McBain Deeds, $\mathrm{n} 1$, pt 1 , pp 19 $\& 37$.

${ }^{12}$ Oral agreements and promises had the least evidential value. However, the word 'parol' (incorrectly and confusingly) was used as a catch all expression to cover any writing other than a sealed writing so that it also covered (f) above. See Rann v Hughes (1778) 7 TR 350n, HL, per Skynner LCB 'all contracts are by the laws of England, distinguished into agreements by specialty, and agreements by parol; nor is there any such third class... as contracts in writing. If they be merely written and not specialties, they are parol.' See also McBain Deeds, $\mathrm{n} 1$, pt 1 , p 37 and McBain Consideration, n 1, pt 2, p 43.

${ }^{13}$ Thus, Crown grants were interpreted most beneficially for the king and against the other party. See W Blackstone, Commentaries on the Laws of England (Oxford, Clarendon Press, $1^{\text {st }}$ ed, 1765-9, University of Chicago Press rep 1979), vol 2, p 347.

${ }^{14}$ These should all be considered together and they stand or fall together. Thus, if the deed is abolished, so should the other two. And if the seal is abolished, so should the deed and the specialty.

${ }^{15}$ For legal persons, see $\mathbf{5}$.

${ }^{16}$ A large amount of the confusion in this area of law is due to the absence of a consistent definition of words such as 'deed', 'specialty' and 'parol.'

${ }^{17}$ See 8.

${ }^{18}$ See 13(b).

${ }^{19}$ Alternatively, it could be called an 'Execution of Legal Documents Act'. Obviously, English law only deals with writings intended to have legal effect (as opposed to moral effect or as a joke etc).
} 


\section{OPENING OBSERVATIONS}

It may be noted, from the outset, that most legal texts on deeds, specialties and seals are dated. ${ }^{20}$ Thus, they should be treated with caution - not least, since the definition of a deed changed greatly as a result of the Law of Property (Miscellaneous Provisions) Act 1989. In the case of notarisation, the general text is Ready (ed), Brooke's Notary. ${ }^{21}$ It may also be noted that - when one considers the formalities for the execution of legal documents - the underlying purpose for them in the past, basically, was threefold, viz. to:

- Prevent fraud (a precautionary function);

- Help evidence the transaction (an evidentiary function);

- Require parties to consider the terms of the document before executing it (a cautionary function). ${ }^{22}$

A major issue, therefore, is whether the present formalities outlined in this article satisfy these underlying purposes. Finally, in this article, royal charters are not considered in detail, although the execution of the same by the great or privy seal is. ${ }^{23}$ Also, not considered are documents of record ${ }^{24}$ since these had disappeared by the Victorian era in respect of commercial matters. Thus, the first legal concept to consider is the deed.

\section{DEEDS}

Prior to analysing a deed, three things may be observed.

- The first, is that the definition of a deed - a sealed writing that was delivered - changed over time. Thus, in the $16^{\text {th }}$ century (c.1562), a further prerequisite was added. To be a deed, the legal document alsohad to be on parchment or paper. Further change occurred in the $17^{\text {th }}$ century when certain deeds (such as awards) were declared by various judges not to be such. More exceptions were enunciated in Victorian times. Then, both in 1925 and in 1989, further changes to the definition of a deed were made - such that it became (and still is) very difficult to define a deed;

- The second, is that the prerequisites of a deed also changed. Thus, sealing began to be replaced, socially, by the signature from the time of Henry VIII (1509-47) and the signature became commonplace by the Victorian era. As for the delivery of a deed, its purpose was to replicate the need for delivery (livery) of seisin (possession) in the case of land transfers -this had become a formality by the time Coke wrote his Institutes of the Laws of England (in 1628). And, by the Real Property Act 1845 , this prerequisite of delivery should have been abolished since the process of transferring land by 'livery of seisin' gave way to the transfer of land by way of grant. Further, the use of parchment became obsolete, in the commercial context, by Victorian times;

- In conclusion, the original description of a deed as a sealed writing that was delivered was at odds with social reality in Victorian times. The prerequisites for a deed still existed in law. However, sealing and delivery had become legal fictions since they did not actually occur (no seal having to be physically attached or actual delivery having to be made);

- The third, is that the benefits of making a legal document by way of a deed declined over time - such that, today, there are only 4 benefits. In respect of these: (a) a deed was interpreted differently to other legal documents. However, by the $20^{\text {th }}$ century, there was no distinction since both were, generally, interpreted the same; (b) consideration was also presumed (imported) in the case of a deed. However, the doctrine of consideration, itself, became of little significance by the 20th century with it always being presumed (or an estoppel held to have arisen); (c) an extended limitation period was accorded in the case of a deed (12 years) as opposed to a 'simple' (i.e. not sealed) contract (6 years). However, in practice, this was of little benefit; (d) privity was also accorded in the case of a deed. However, legislation now deals with this in most instances.

\footnotetext{
${ }^{20}$ For many of them, see McBain Deeds, n 1, pt 1, pp 31-2. The best modern statement is in Halsbury, see n 1. However, it is scant, especially as to the legal history of deeds.

${ }^{21}$ NP Ready, Brooke's Notary ( ${ }^{\text {st }}$ ed, $1839 ; 14^{\text {th }}$ ed, 2013).

${ }^{22}$ McBain Deeds, n 1, pt 1, pp 15 \& 32, n 3.

${ }^{23}$ See also GS McBain, Modernising the Monarchy in Legal Terms: Part 5 (2014) King's Law Journal, pp 440-1.

${ }^{24}$ Formerly, English courts were distinguished between courts of record (being all the king's courts) and those not of record. In the king's courts, writings (including deeds and debts) could be enrolled and become part of the record. Once enrolled, the possibility of the rolls being tampered with was much reduced. As a result, considerable judicial reliance could be placed on them. Because of the presumed accuracy of recorded writings, an expedited species of trial - trial by record - arose. Where a matter of record was pleaded, the court ordered the record to be produced and the issue was settled on that point alone. No jury was required. This category of writing effectively disappeared when writings were no longer enrolled (registered) in court records, a practice which was discontinued from the 1870's in the case of most deeds (deed polls on a change of name being an exception). See McBain Deeds, n 1, pt 1, p 18.
} 


\section{(a) Concept of a Deed}

The legal concept of a 'deed' was unknown to Anglo-Saxon law. Indeed, the making of any legal document was rare - given the high rates of illiteracy. Thus, writing was restricted to the king and a few clerics and magnates. Further, they did not 'sign' a legal document as we understand it today. That is, by writing their signature. Instead, they put their 'mark' on it. Usually, in the form of a cross which was placed beside a clerk's subscription of their name. ${ }^{25}$

- With the arrival of the Normans after the Norman Conquest (1066), any writing (latin, carta) was called a 'charter'. These became categorised into royal charters (also, called diplomas) and private charters (i.e. legal documents executed by private individuals) $;^{26}$

- Gradually, the word 'charter' became a word used to describe a writing executed by the monarch only. As a result, the word 'deed' (in ordinary parlance, the word referred to an 'act' or ' $f a c t$ ') $)^{27}$ came into its own. It referred to a writing - invariably on parchment (paper did not come into England until the $14^{\text {th }}$ century) that was sealed and delivered. Thus, a deed was a type of legal document - a description of a particular legal 'act';

- As to when the word 'deed' became recognised, and commonly used, in legal terminology, this was probably c.1290-1300. Further, there was nothing complicated about it. If the Normans could have signed their name, a 'deed' would have been a reference to a signed writing, the signature being evidence of a party agreeing to be legally bound - save for the additional requirement of delivery (see below);

- As for the seal, the Normans introduced the seal from ecclesiastical practice. At first, the seal was restricted to the king and powerful nobles. However, by c. 1166, lesser magnates were using it. And, by 1290 , it was ubiquitous among wealthier people and merchants. ${ }^{28}$

Thus, the deed was the same as any other writing in early medieval times save for the requirement of delivery. In short, a deed was a particular type of legal document. One which also required delivery to be effective. If not it was a mere escrow or escrowl (a writing, albeit sealed). ${ }^{29}$ As for this prerequisite of delivery - and its purposive element - one needs go back into Biblical times for an explanation. In order to avoid fraud (and disputes), all transactions - to have legal validity - had to be 'ceremonial' (that is, formal) in nature. Thus, a person physically handed over the object in question - or a token to represent the same (such as a shoe in the case of land) - to another, in order to effect a legal transaction such an exchange, sale or gift. This occurred in the presence of witnesses. This delivery (livery) of possession (seisin) was essential so that everyone could see (and remember) that someone had conveyed title to another. Formulaic words were also employed. ${ }^{30} \mathrm{~A}$ failure to satisfy these formal requirements invalidated (voided) the transaction. This process also applied in AngloSaxon law - doubtless, because their law was, mainly, written by clerics who were familiar with Biblical law. Thus, there was physical (or representational) delivery with formulaic words and witnesses. ${ }^{31}$ However, postConquest, as the English population and commerce increased, physical attendance by the contracting parties (and witnesses) became more onerous and this impacted on the need for the physical delivery of the object in question (land, goods etc).

- Incorporeal Hereditaments. ${ }^{32}$ Thus, in Norman times, agents were used to stand in for the contracting parties, starting with the king and spreading downwards in society (this producing the power of attorney). Further, it was inevitable with incorporeal hereditaments that the delivery of a legal

\footnotetext{
${ }^{25}$ See McBain Deeds, n 1, pt 1, p 20 and McBain Consideration, n 1, pt 1, p 37.

${ }^{26}$ Thus, Glanvill (c. 1189), n 7, in the first English legal text, distinguished a royal charter from a private one (he called the latter a chirographic charter), see McBain Deeds, n 1, pt 1, p 16. So did Bracton (c. 1250), Ibid. Both, also, referred to a charter being sealed by its maker.

${ }^{27}$ McBain Deeds, n 1, pt 1, pp 16 \& 33.

${ }^{28}$ See McBain Deeds, n 1, pt 1, p 20 and McBain Consideration, n 1, pt 1, p 45, fn 418 (referring to a trial c. 1154). The seal of another could be used if one did not have one of one's own, see McBain Deeds, n 1, pt 1, p 21 and p 40, n 167.

${ }^{29}$ Ibid, p 23 referring to Paston JCP in a case in 1431 'It is nothing more than an escrow unless he delivers the deed to him.' See alsoBlackstone, n 13, vol 2, pp 305-6 'the Normans, a brave but illiterate nation...used the practice of sealing only, without writing their names: which custom continued, when learning made its way among them, though the reason for doing it had ceased...At the conquest, the Norman lords brought over into their kingdom their own fashions; and introduced waxen seals only, instead of the English method of writing their names, and signing with the sign of the cross.'

${ }^{30}$ See McBain Consideration, n 1, pt 1, pp 17-25.

${ }^{31}$ Ibid, pp 34-41. See also GS McBain, Modernising the Law of Gift (2016) International Law Research, vol 5, no 1, p 172.

${ }^{32}$ Incorporeal hereditaments comprise things such as advowsons, tithes, commons, ways, offices, dignities, corrodies or pensions, annuities and rents. See Blackstone, n 13, vol 2, p 21. Also, McBain Deeds, n 1, pt 1, p 33
} 
document would be treated as sufficient to the transfer of title to the same since they had no physical element. As aresult, the transfer (conveyance) of a sealed writing was sufficient by the time of Britton (c.1290) to constitute the transfer (conveyance) of an incorporeal hereditament; ${ }^{33}$

- Personalty. By legal extension, it was, then, accepted by the English courts that personalty could be transferred by deed. This had occurred by $1385,{ }^{34}$

- $\quad$ Land. In the case of land, change took much longer so great was the time honoured custom of land being physically transferred. That is, the landowner on (or in view of) the land physically transferring his title to another in the presence of witnesses, by handing over possession (seisin) of it pursuant to a ceremony. ${ }^{35}$ Thus, handing over a deed of title was - at first - no more than additional evidence of the transfer of title physically. Then, the English courts permitted evidence of legal acts (private agreements) concerning land (fines, final concords or agreements) to be recorded in the court rolls, post 1195 . And, they were prepared to recognise such evidence 'on the record' as being of especial evidential value for judicial purposes. ${ }^{36}$ Recognition of the 'deed' as a legal concept enabled English law to take this one stage further. In time, the courts (or legislation) recognised that land could be validly transferred by employing devices which did not involve physical delivery, such as uses, bargain and sale, lease and release etc.

In conclusion, the legal concept of a deed was a sealed writing on parchment (or paper) which became effective on delivery.

\section{(b) Definition of a Deed}

When the term 'deed' (factum in latin and fait, fet in Anglo-Norman) was first employed in legal terminology to define a sealed writing that had been delivered by one party to another, is unclear. Such would have been gradual. ${ }^{37}$ Pollock and Maitland hypothesised that the technical use of the word 'deed' was the outcome of the common plea non est factum meum ('I did not execute that document') ${ }^{38}$ This would seem likely since the parchment, as sealed, was evidential - something to plead in court viz. that the maker had executed it, thereby, accepting that it was his legal act and that he was legally bound. Likely, this had occurred by $1290 .{ }^{39}$ In 1444 , Fulthorpe JCP made it clear that a deed (' $f a i t$ ') required writing, sealing and delivery ${ }^{40}$ as did Rastell in $1527,{ }^{41}$ Perkins in $1532{ }^{42}$ and Goodard's Case (1584) ${ }^{43}$ Coke (in 1628) stated an oft quoted definition of a deed:

\footnotetext{
${ }^{33}$ Britton (trans Nichols, 1865), vol 1, p 366 'But for the purchase of these franchises [i.e. incorporeal tenements] the same formality of giving seisin is not requisite, as in purchases of corporeal things. For if the parties are agreed, the delivery of the deeds together with the view of the tenements in the presence of neighbours is sufficient.' See also McBain Deeds, n 1, pt 1, p 33, n 38.

${ }^{34}$ McBain Consideration, n 1, pt 2,p 50 citing J Baker, An Introduction to English Legal History (Reed, $4^{\text {th }}$ ed, 2002),p 384 'by the end of the fourteenth century a gift of chattels could be effected by deed.' Baker cited Pynchoun v Geldeford (1385) YB Hil 8 Ric II (Ames Foundation, 1987), p 215.

${ }^{35}$ See McBain Deeds, n 1, pt 1, pp 20-1. For the ceremony under early Scots law, see Ars Notariatus, n 1, pp 56, 67 \& 75 (delivery of earth and stone to symbolize the land or entry through the door of the house).

${ }^{36}$ Blackstone, n 13, vol 3, p 331 'as Sir Edward Coke observes, a record or enrollment is a monument of so high a nature, and importeth in itself such absolute verity, that if it be pleaded that there is no such record, it shall not receive any trial by witness, jury, or otherwise, but only by itself.' See also E Coke, Institutes of the Laws of England (W Clarke \& Sons, London, last ed, 1824), vol 1, s 175 (Co Litt $117 \mathrm{~b}$ ). See generally, McBain Deeds, n 1, pt 1, pp 18 \& 37.

${ }^{37}$ Hyams, The Charter as a Source for Early Common Law (1991) Journal of Legal History, vol 12, no 3, p 173 'The process by which a man's deed ('factum') became equated with the parchment that recorded it was a gradual one.' See McBain, n 1, pt 1, p 34, n 42.

${ }^{38} \mathrm{~F}$ Pollock \& FW Maitland ('P \& M'), History of English Law before the time of Edward I ( ${ }^{\text {nd }}$ ed, 1898), vol 2, p 221. See also McBain, $\mathrm{n} 1, \mathrm{pt} 1, \mathrm{p} 34, \mathrm{n} 43$.

${ }^{39}$ Ibid, p 220. P \& M thought that, by the late $13^{\text {th }}$ century, "by a deed (fet, factum) men are beginning to mean a sealed piece of parchment... The sealing and delivering of the parchment is the contractual act.' Also, 'As a word which will stand for the document itself, it slowly surplants carta; it is thus used in YB 33-5 Edw 1 [1305-7], p 331: 'nous avoms vostre fet.' The Statute of Gloucester 1278 used the word 'fet' to refer, in translation, to a 'fact', 'act', 'deed', see c. 9 ('ou le fait fuist fait', where the act was done), See also Coke, n 36, vol 2, p 317.

${ }^{40} 22$ Hen 6 pl 33 fo $45 \mathrm{a}-46 \mathrm{a}$ (1444), Seipp no 1444.033 per Fulthorpe JCP, 'The defendant has pleaded only the delivery of an escrow because if the deed is to be [will be] effective he must have a sealed writing and delivery of the deed' ('le defendant en effect ad monster forsque livere d'un escrow, car s'il sera effectual fait il doit aver escript enseale et deliverie de le fait.').

${ }^{41}$ W Rastell, Exposition of certain Difficult and Obscure Words and Terms of the Law ( ${ }^{\text {st }}$ ed (latin) 1527, 1563 ed), 'every deed consisteth of three principal points (and if those three be not joined together, it is no perfect deed to bind the parties) namely writing, sealing and delivery.' The latin edition was titled 'Expositiones Terminorum Legum Anglorum'.

${ }^{42}$ J Perkins, Profitable Book (1532, trans) 'there are three things necessarily appertaining unto a deed; viz. writing, sealing and delivery.' (repeated in 1757 ed). The first latin edition was in 1528, the first law French edition was in 1555, the first English edition was in 1642.

${ }^{43} 2$ Co Rep 4b, 5a (76 ER 396) 'there are but three things of the essence and substance of a deed, that is to say, writing in paper or parchment, sealing and delivery.'
} 
'A deed, factum. This word (deed) in the understanding of the common law, is an instrument written in [on] parchment or paper.'

Also, 'Deed (fait). Factum, anglice [in English], a deed, and signifieth in the common law, an instrument consisting of three things, viz. writing, sealing, and delivery, comprehending a bargain or contract between party and party.' 44

However, Coke was in error as to a deed being restricted to a 'bargain or contact'. It was not until $R v$ Morton $(1873)^{45}$ that the court clarified that deeds were not limited to contracts, removing this lapse of Coke. Other errors then crept in.

- In Dod v Herbert (1655) ${ }^{46}$ the court held that an award was not a deed - only a sealed writing. Then, in Hibblewhite v McMorine (1840) ${ }^{47}$ Parke B declared that warrants of justices, sub-poenas and awards were not deeds and, in Chanter $v$ Johnson $(1845),{ }^{48}$ he said the same of a licence under seal to use a patent;

- In $R v$ Morton (1873), Bovill CJ restricted deeds to legal documents (instruments) which passed an 'interest or property. ${ }^{49}$

These new (and rather idiosyncratic) definitions confused the prior concept prevailing since the medieval ages that a deed was a sealed writing on parchment (or paper) that was delivered. The result was confusion as regards the definition of a deed.

\section{In conclusion, the definition of a deed changed over time.}

\section{(c) Change to the Nature of the Prerequisites of a Deed}

As well as changes to the definition of a deed - over the centuries - major changes occurred to the prerequisites of delivery and sealing. Also, the need for the writing to be on parchment or paper. Thus:

- $\quad$ Delivery. There was a gradual diminution in the need for actual delivery leading to the same becoming a legal fiction. By the $16^{\text {th }}$ century, the fact of delivery did not have to be stated in the deed, as noted in Goddard's Case (1584). ${ }^{50}$ Later, delivery became constructive. ${ }^{51}$ This is explicable by reason of the fact that the need for the deed to represent physical delivery was in decline since - even in the case of land - it was no longer required. Transfer (that is, livery or delivery) of seisin (possession) was superceded by more commercially convenient forms of title transfer. The death knell for the prerequisite of delivery was the Real Property Act 1845. It enacted that, in future, corporeal hereditaments were to lie in grant and not by way of livery of seisin. As Alexander noted, this was a decisive break with the past and it meant that the delivery of a deed was now an otiose prerequisite. ${ }^{52}$ As it was - even before this date - the courts had reduced 'delivery' as a prerequisite for a

\footnotetext{
${ }^{44}$ Coke, n 36, vol 1, s 40 \& vol 2, s 259 (Co Litt 35b, 171b). See also Blackstone, n 13, vol 2, p 295 'a deed is a writing sealed and delivered by the parties. It is sometimes called a charter, carta, from its material; but most usually, when applied to the transactions of private subjects, it is called a deed, in latin factum...because it is the most solemn and authentic act that a man can possibly perform, with relation to the disposal of his property.' See McBain, n 1, pt 1, p 17.

${ }^{45}$ LR 2 CCR 22 at p 27 per Bovill CJ 'In some of the definitions given a deed is described as being something of the nature of a contract. But the term is clearly not confined to contracts.' See also McBain, n 1, pt 1, p 34, n 59.

${ }^{46}$ Styl 459 .

${ }^{47} 6 \mathrm{M} \& \mathrm{~W} 200$.

${ }^{48} 14 \mathrm{M} \& \mathrm{~W} 408$.

${ }^{49}$ See n 45, p 27 per Bovill CJ 'any instrument delivered as a deed, and which either itself passes an interest or property, or is in affirmance or confirmation of something whereby an interest or property passes, is a deed.' This definition failed to cover a release. See McBain Deeds, n 1, pt 1, p 18 and pp 34-5. See also Halsbury, n 1, vol 32, para 201 which lists other legal documents which - although sealed - have been held not to be deeds. There is little (no) legal consistency to them.

${ }^{50} 2$ Co Rep 4b (76 ER 396)'delivery is as necessary to the essence of a deed, as the putting of the seal to it, and yet it need not be contained in the deed that it was delivered. And note, the order of making a deed is, first to write it, then to seal it, and after to deliver it: and therefore it is not necessary that the sealing or delivery be mentioned in the writing, for as much as they are to be done after. And so, it was said, it was resolved in Henry the Eighth's time [i.e. 1509-47].' See also McBain Deeds, n 1, pt 1, p 29.

${ }^{51}$ Coke, n 36, vol 1, s 40 (Co Litt 36a)(in 1628) 'as a deed may be delivered to the party without words, so may a deed be delivered by words without any act of delivery, as if the writing sealed lieth upon the table, and the feoffor or obligor saith to the feoffee or obligee, Go and take up the said writing, it is sufficient for you, or it will serve the turn; or Take it as my deed, or the like words, it is sufficient delivery.' See also Chamberlain v Stanton (1588) Cro Eliz 122 (78 ER 379) and Thoroughgood's Case (1584) 2 Co Rep 9a, 9b (76 ER 408).

${ }^{52}$ CG Alexander, Recent Developments in Conveyancing Law in Cambridge Legal Essays (Heffer \& Sons, 1926), p 24 'The importance of this Act in the history of conveyancing it would be difficult to overestimate. Henceforth all land of freehold tenure could be conveyed by deed, one deed, and that deed usually a simple grant. This Act of 1845 marks definitively the break of our law with the old feudal system.' A Underhill, Changes in the English Law of Real Property during the Nineteenth Century in Selected Essays in Anglo-American Legal History (Little, Brown \& Co, Boston, 1909), vol 3, p 706 'the old common law theory that actual delivery of possession, or the newer theory that a
} 
deed to a fiction, it only being a matter now of intention. ${ }^{53}$ Thus, by this stage (1826), delivery should have been dispensed with since it had served its purpose. As it was, a conclusive presumption as to the delivery of a deed arose both at common law and in legislation; ${ }^{54}$

- $\quad$ Sealing. The seal was to cope with the inability of the Normans to sign. However, by the time of Henry VIII (1507-49), people were beginning to sign and this became the norm by Victorian times, if not before. Further, the seal attached to the parchment (or paper) had always been nominal since it replaced a person physically handing over his personal seal (signet) each time he effected a legal transaction, to evidence his being legally bound. ${ }^{55}$ Being nominal in nature (reflecting the intention to be legally bound), a seal could be any shape, size or colour. It could also be plain and plain wafer seals (often, coloured red) were in widespread use from the 1840's. Thus, by this time, the seal should have been abolished and the signature recognised as being sufficient for a deed. As it was, the courts came to accept that any evidence of a seal was sufficient - including just employing the word 'sealed'. Also, a conclusive presumption of sealing arose both at common law and in legislation (as had occurred in the case of delivery, see above) ${ }^{56}$

- $\quad$ Parchment. This prerequisite (arising from judicial decision c. 1562) was obsolete by Victorian times when paper replaced parchment in commercial usage. However, it was not until the Law of Property (Miscellaneous Provisions) 1989 that the prerequisite of parchment or paper was abolished.

In conclusion, the key prerequisites for a deed - parchment, sealing and delivery - had become obsolete by 1845 (Real Property Act 1845).

\section{(d) Opaque Definition of a Deed}

As noted previously (see (b)), confusion arose as to what was a deed since - even though a writing was on paper and parchment and sealed and delivered - some deeds were not treated as such, but merely as sealed instruments. The result was that it became difficult to define a deed - a point noted in standard texts on the same by Elphinstone (in 1884) and by Norton (in 1906). ${ }^{57}$ This lack of clarity has prevailed until modern times. A definition of a deed given by the Law Commission in 1998 was similarly opaque. ${ }^{58}$

In conclusion, by early Victorian times, the deed should have been abolished since: (i) parchment was no longer used in commercial transactions; (ii) delivery was otiose; and (iii) the seal, in the social and commercial context, had been superceded by the signature (in any case, no seal needed to be attached). However, since the law often lags behind social and commercial realities, such was not done.

notional delivery by the aid of the Statute of Uses [1536] was necessary to a transfer of land, was swept into the limbo of pedantic rubbish, and a simple deed of grant was sufficient. This deed of grant is still the common form of conveyance.' See also McBain Consideration, $\mathrm{n}$ 1, pt 2, p 50 and F Pollock, Jurisprudence and Legal Essays (Macmillan, 1961), pp 103-4. See also Law of Property Act 1925, s 51(1) 'All lands and all interests therein lie in grant and are incapable of being conveyed by livery or livery and seisin....'

${ }^{53}$ See Doe d Garmons v Knight (1826) 5 B \& C 671 (108 ER 250) per Bayley J at p 692. See also Xenos v Wickham (1867) LR 2 HL 296 at p 312 per Blackburn J. Also, Macedo v Stroud [1922] 2 AC 330 per Viscount Haldane at p 337 'as soon as there are acts or words showing that it is intended to be executed as his deed that is sufficient.' See also McBain Deeds, n 1, pt 1, pp 29 \& 52 and McBain Consideration, $\mathrm{n} 1$, pt 2, p 50 .

${ }^{54}$ See McBain Deeds, n 1, pt 1, p 29. In Alan Estates Ltd $v$ WG Stores Ltd [1982] Ch 511, 520 per Lord Denning MR, a declaration in a deed that it had been 'signed sealed and delivered' was sufficient to raise a conclusive presumption of delivery. Ibid, pt 1 , $\mathrm{p} 52$. See also Companies Act 1985, s 36A(5) and s 36A(6) (see now Companies Act 2006).

${ }^{55}$ The Romans employed the same method, formally handing over a ring (sent with a slave) to confirm the conclusion of a legal transaction. Also, for the institution of an heir, the testator gave a ring, see Ars Notariatus, n 1, p 138.

${ }^{56}$ McBain Deeds, n 1, pt 1, p 26. In Re Sandilands (1871) LR 6CP 411, 413 the mere indication of a seal, a ribbon coupled with evidence of delivery by the maker as his deed, was sufficient. In Re Balkis (1888) 58 LT 300 a circle round the words 'place for seal' probably sufficed. In Commercial Services v Knowles (1978) [1978] CLY 794 it was held that the words 'signed, sealed and delivered' performed the same function as a seal. In TCB v Gray [1986] Ch 621 a deed stating that it had been sealed, was held to have created an estoppel even though it had not been sealed. See McBain Deeds, n 1, pt 1, p 26 \& 46.

${ }^{57}$ See McBain Deeds, n 1, pt 1, p 17. Norton hazarded the following definition 'A writing (i) on paper, vellum or parchment, (ii) sealed and (iii) delivered, whereby an interest, right, or property passes, or an obligation binding on some person is created, or which is in affirmance of some act whereby an interest, right or property has passed.' Ibid.

${ }^{58}$ The Law Commission defined a deed as: 'A written instrument which is executed with the necessary formality, and by which an interest, right, or property passes or is confirmed, or an obligation binding on some person is created or confirmed.' See McBain Deeds, $\mathrm{n}$ 1, $\mathrm{pt}$, $\mathrm{p}$ 18. However, this is opaque since a written instrument is the same as a legal document. Thus, the latter expression is simpler. Further 'with the necessary formality' fails to state what is actually required. The remainder of the definition derives from Bovill CJ (see $\mathrm{n} 49$ ). See also Halsbury, n 1, vol 32, para 201 'it must express that the person or corporation so named makes, confirms, concurs in or consents to some assurance (otherwise than by way of testamentary disposition) of some interest in property or of some legal or equitable right, title, or claim, or undertakes or enters into some obligation, duty or agreement enforceable at law or in equity, or does or concurs in some other act affecting the legal relations or position of a party to the instrument or of some other person or corporation.' 


\section{(e) Current Position \& Complexity}

Reform to the law on deeds was slow in coming. Recognition of the signature occurred in 1925 with it being a requirement that an individual must sign an instrument (or have another sign it on his behalf) in order to make it a deed. ${ }^{59}$ And, since the Law of Property (Miscellaneous Provisions) Act 1989, a deed is no longer required to be sealed by an individual. In 1983, the Law Commission (in a Working Paper) provisionally recommended the abolition of delivery as a prerequisite, on the basis that it could be a 'dangerous misnomer' ${ }^{60}$ However, this did not occur - a pity, since this would have meant that there was, in reality, no difference between a deed and any other legal document (save for the archaic use of a seal). The requirement that a deed must be on parchment or paper was removed by the Law of Property (Miscellaneous Provisions) Act 1989. This, also, should have been the opportunity to abolish deeds. Yet, the Law Commission (effectively) preserved the deed by recommending two new prerequisites - a deed had to: (i) make it clear on its face that it was such (a 'face value test'); and (ii) in the case of an individual, that it had to be attested.

- However, these new prerequisites were, simply, makeweights to prevent deeds being no different to specialities or to any other sealed instrument (writing);

- Further, (i), in effect, contradicted the general proposition of law that is for the courts to legally categorise the nature of a legal document and not the maker. ${ }^{61}$ Further, declaring a document to be a deed does not, necessarily, make it so in law. ${ }^{62}$ This new requisite also reversed the position at common law and in the Law of Property Act 1925, s 57 (description of deeds) in which a deed did not have to state on its face that it was such;

- As for, (ii), the prerequisite of attestation could result in a valid legal document being rendered invalid by a formal requirement. As a result, in Shah v Shah (1982), the Court of Appeal ignored this prerequisite (see 10(c)).

The result of all this historical confabulation is that most lawyers (and judges) - and certainly all laymen - when considering the law of deeds, might be tempted to exclaim 'this sames a labyrinth'. Indeed, it is, since there is:

- no generally accepted definition;

- the legal distinctions between a deed, a speciality and a sealed instrument are unclear;

- when a legal document must be way of deed at common law or pursuant to legislation is complex, confusing and inconsistent; ${ }^{63}$ and

- there are (at least) 7 different means of executing a deed - depending on whether it is made by: (i) an individual; (ii) a corporation sole; (iii) a company under the Companies Acts (or an unregistered company); (iv) a foreign company; (v) another form of corporation aggregate; (vi) a limited liability partnership; (vii) the palatinate (and the duchy) of Lancaster and the duchy of Cornwall. ${ }^{64}$

\section{(f) Abolishing Deeds}

The argument for abolishing deeds is predicated on the essential fact that a deed is, at base, no different to any other legal document save that it preserves the need for a seal (other than for individuals). However, the seal has been replaced in general social and commercial use by the signature for, at least, 150 years. Further - even in the case of legal persons - the present tendency, today, is to sign as opposed to seal. Thus, if the seal is abolished, so too, should the legal concepts of deeds and specialties since their continuing raison d'etre relates to the seal as the key feature which distinguishes them from other legal documents. Abolishing deeds would also remove a vast quantity of confused and anomalous law. Further, it would help make the law more consistent since many writings intended to have legal effect which - one would think the law would require to be made by way of deed

\footnotetext{
${ }^{59}$ Law of Property Act 1925, s 73 (rep). See also McBain Deeds, n 1, pt 1, pp 17 \& 35.

${ }^{60}$ See McBain Deeds, n 1, pt 1, p 30.

${ }^{61}$ Esso Petroleum Co Ltd v Custom \& Excise Commissioners [1973] 1 WLR 1240 per Pennycuick VC 'the nature of the transaction depends upon the terms upon which the parties entered into it and not upon the label which the parties attached to it...'. See also McBain Gift, n 31 , p 199.

${ }^{62}$ For example, although a legal document executed by an individual may declare itself to be a deed, if not attested, it is not. In Johnsey Estates (1990) Ltd v Newport Marketworld Ltd \& Others (unreported decision in 1990), it was held that the fact that a contract was executed under seal was sufficient intent to create a deed. However, this negates any face value requirement (as well as treats specialties and instruments under seal as deeds). The Law Commission disagreed with this decision. See McBain Deeds, n 1, pt 1, pp 30 \& 54 , n 454.

${ }^{63}$ Halsbury, $n$ 1, vol 32, paras 210-26.

${ }^{64}$ See McBain Deeds, n 1, pt 1, p 17, where these are set out (relevant sections are now in the Companies Act 2006).
} 
- are not and here, also, there is great inconsistency and illogicality. ${ }^{65}$ However, if deeds are abolished, it needs to be considered whether any benefits accorded to them should be extended to other legal documents. This, to forestall any complaint that some legal benefit is being 'lost' in some way if deeds no longer exist. Such is now considered.

\section{(g) Benefits of a Deed ${ }^{66}$}

- $\quad$ Merger. If a debtor enters into a deed (or a specialty) to secure a debt (or other obligation) owed by him under a simple contract, the remedy under the latter merges into the superior remedy under the deed (or specialty). However, for this to happen: (i) the security must be taken in respect of the same obligation; (ii) it must be of higher efficacy; (iii) the transaction must be between the same parties; and (iv) the parties must, generally, intend merger to occur (this rarely happens since their intention is not focused on the same). Today, the only real benefit of merger is an extended limitation period (see below). Thus, if deeds are abolished, abolishing this benefit would result in no loss; ${ }^{67}$

- $\quad$ Limitation Act 1980. Under this Act, the limitation period for a specialty (which is taken to include a deed and, likely, covers any sealed writing) is 12 years, but 6 years for a simple contract. If deeds and specialties are abolished, if necessary, the limitation period for any legal document could be set at 12 years (or it could be limited to that for contract debts, i.e. 6 years). This would seem reasonable since people are living longer and commercial acts (and litigation) can take longer. It would also remove any distinction between contracts and other legal documents vis-a-vis a limitation period. ${ }^{68}$ Thus, if deeds are abolished, any extended limitation period could be applied to legal documents generally, making the law more consistent;

- Interpretation. This has a long and chequered history. A deed may be interpreted differently to another form of writing. In particular, a party to a deed might be estopped to a greater extent. The problem with so many of these (arcane) rules for the interpretation of deeds was that they arose from historical events and they had little (or no) reference to modern commercial and social realities. Nor, indeed, to common sense. The death knell to retaining a separate set of rules is the decision of the House of Lords in Investors Compensation Scheme Ltd v West Bromwich Building Society (1998) in which the House recognised that the old 'intellectual baggage' of interpretation in respect of deeds had been discarded. ${ }^{69}$ Today, those rules of interpretation for deeds that remain ${ }^{70}$ and which are useful now apply to legal documents in general. Thus, if deeds are abolished, abolition of rules on their interpretation would result in no loss. ${ }^{71}$

One would suggest that two of the above (merger and interpretation) are minor and that a review of them would not take much time. Further, the benefits they bring (in practice) are small. The Limitation Act 1980 point is also minor and the limitation period for deeds should now be consistent with simple contracts (whether by increasing the time period in the case of the latter or decreasing that in the case of the former).

- $\quad$ Privity. The common law rule was that, generally, a contract could not confer rights (or impose obligations) on a person not party to it. This was affected by the Contracts (Rights of Third Parties) Act 1999. Abolition of deeds would improve the position re privity, since the position in respect of deeds is old and obscure. ${ }^{72}$ However, to avoid any allegation that something is being lost, privity - as applied to

\footnotetext{
${ }^{65}$ Thus, wills have never had to be by way of deed even though, given their nature one would assume that they should be accorded the highest degree of formality. Absolute bills of sale do not have to be by way of deed (cf. security bills). Nor bills of exchange or promissory notes. Nor the grant of some legal estates in land or the transfer of some shares or many choses in action. See McBain Deeds n 1, pt 1, p 19. ${ }^{66}$ See generally, McBain Deeds, $n$ 1, pt 2, pp 3-9.

${ }^{67}$ McBain Deeds, n 1, pt 2, p 9 and McBain Consideration, n 1, pt 2, pp 92-3. A deed also imports certain statutory provisions pursuant to the Law of Property Act 1925, ss 101 and 103 (certain powers conferred on a mortgagee if the mortgage is by way of deed). These provisions are very rarely availed of and these sections can be amended to cover legal documents in general, by excising the references to deeds. See McBain Deeds, n 1, pt 2, p 8.

${ }^{68}$ Ibid, p 9. See also McBain Consideration, n 1, pt 2, pp 93.

${ }^{69}$ [1998] 1 AE 98, 114 per Lord Hoffman 'Almost all the old intellectual baggage of 'legal' interpretation has been discarded.' See also McBain, n 1, pt 2, pp 4 \& 17.

${ }^{70}$ The original rules for the interpretation of deeds from the time of Bracton (c. 1250) have become part of general law, see McBain Deeds, $\mathrm{n}$ 1 , pt 2 , pp $4 \& 17$.

${ }^{71}$ Ibid, pp 4-6 and 9. See also McBain Consideration, n 1, pt 2, p 93.

${ }^{72}$ McBain Deeds, $\mathrm{n}$ 1, pt 2, pp 7-8 and McBain Consideration, $\mathrm{n} 1$, pt 2, p 93. The only issue $r e$ a deed would appear to be that of privity in the case of a declaration (commonly called a 'deed poll' - although this is a misnomer since no 'polling' is required and such can be made by more than one party) since privity inter partes now seems to be adequately covered by legislation. See McBain Deeds, n 1, pt 2, p 8 and Halsbury, n 1, vol 32, paras 261-6.
} 
deeds - could be extended to legal documents in general where the same would, otherwise, have applied in respect of a deed;

- Consideration. A deed imports (i.e. gives rise to a presumption of) consideration, a prerequisite for a contract. The need for consideration (a prerequisite not found in civil legal systems) has been much disputed and it (likely) should be abolished. ${ }^{73}$ Further, as long ago as 1765 (Pillans v Van Mierop), Mansfield CJ sought to apply the doctrine of consideration to any legal writing since the doctrine, at base, is a matter of evidence - an intention to be bound as a result of paying, or receiving, money or money's worth. ${ }^{74}$ However, in the interim - to avoid any allegation that something is being lost - the presumption of consideration - as applied to deeds - should be extended to any legal document (of even greater clarity would be to define a contract and its prerequisites, omitting the need for consideration).

One would suggest that the issue of consideration is also a minor point. And, that privity should now apply to any legal document since the Contracts (Rights of Third Parties) Act 1999 has done this for contracts.

In conclusion, deeds are well past their 'sell-by' date. Obscure, confused and confusing the only grounds for their present retention relate to the supposed benefits they bring. At most, these are 4 (see (g) above) since merger would go if deeds were abolished. As to the remainder, one (interpretation) is of no worth and the issue as to the limitation period can be easily resolved. The other two (consideration and privity) can be easily dealt with by extending them to other legal documents which - in the case of consideration - was what was sought by Mansfield CJ in Pillans v Mierop (1765). ${ }^{75}$

\section{SPECIALTIES \& SEALED INSTRUMENTS}

\section{(a) Nature of a Specialty}

As noted elsewhere ${ }^{76}$ under English law, the concept of a specialty - and its relationship with a deed - has always been unclear, despite having a long historical pedigree. There would seem to be various possibilities as to the meaning of a 'specialty' viz. that it is:

- a type of deed. In particular, one evidencing a debt;

- $\quad$ an instrument under seal. That is, a speciality is an instrument under seal;

- a generic reference which refers both to a deed and to an instrument under seal; ${ }^{77}$

- a distinct legal concept.

Blackstone (in 1766) seems to have treated a specialty as a type of deed - one acknowledging a contractual $\mathrm{debt}^{78}$ (although this is not wholly clear since he also referred to an instrument under seal and such is not identical to a deed). ${ }^{79}$ If so, a speciality is one and the same as a deed. At least, in most instances, which is how it has been tended to be treated by legal writers and the Law Commission in later times. ${ }^{80}$ Thus, in 1998, the Law Commission recommended that it should be made clear that - for an instrument to be a specialty at common law - it must be a deed. ${ }^{81}$

- However, it seems that a speciality is not the same as an instrument under seal. Thus, an award is not a specialty since it does not evidence a debt. Instead, an instrument under seal would cover an award as well as warrants of justices, sub-poenas, a licence under seal to use a patent $e t c{ }^{82}$

\footnotetext{
${ }_{73} 3$ Burr 1663 (97 ER 1035), See also McBain Consideration, n 1, pt 2, p 34 and McBain Deeds, n 1, pt 2, pp 6-7.

${ }^{74}$ Sometimes, it is asserted that a deed imports (presumes) consideration and, sometimes, that the formality of a deed estops a party to the deed from asserting a lack of consideration. However, at base, both are the same. It was not the deed (the writing) that was the relevant point. It was the formality of the seal. The seal (or a signature) evinced the intention to be bound which a party should not be, later, entitled to gainsay.

${ }^{75}$ McBain Consideration, n 1, pt 2, p 93. Cf. W Holdsworth, A History of English Law (Sweet \& Maxwell, 1925, 2009 rep). He proposed that, where a contract in writing was validly executed (i.e. signed), consideration should be presumed.

${ }^{76}$ McBain Deeds, n 1, pt 1, pp 9-11.

${ }^{77}$ The Limitation Act 1980, s 8 reflects this, stating: 'An action upon a specialty shall not be brought after the expiration of [12] years from the date on which the cause of action accrued.' (italics supplied).

${ }^{78}$ Blackstone, n 13, vol 2, p 465 'Debts by specialty, or special contract, are such whereby a sum of money becomes, or is acknowledged to be, due by deed or instrument under seal. Such as by deed of covenant, by deed of sale, by lease reserving rent, or by bond or obligation.' See McBain Deeds, n 1, pt 2, p 9.

${ }^{79}$ One says 'not wholly clear' since Blackstone stated 'by deed or instrument under seal.' Therefore, he could have regarded a specialty as embracing both a deed and an instrument under seal.

${ }^{80}$ See McBain Deeds, n 1, pt 2, p 10.

${ }^{81}$ Ibid.

${ }^{82}$ See ns 46-9.
} 
- In times past, a sealed tally (a tally being on wood) was not treated as a deed, even if there was writing on it, since the writing was not held to be sufficiently permanent in contrast to a deed which was on parchment. ${ }^{83}$ However, a sealed tally was treated as a specialty - lending credence to a specialty being (in times past) a distinct legal concept;

- $\quad$ Further, the requirement that a deed must state that it is such on its face (introduced since 1989) means that specialties must still exist, since specialties by statute do not have to do so. ${ }^{84}$ Further, a debt contained in an instrument under seal made by an individual which is not attested is not a deed. However, it could be a specialty, if the latter is a distinct legal concept.

In conclusion, it is better to treat (out of caution) a specialty as a distinct legal concept which refers to a debt contained in a legal document under seal, not otherwise satisfying the requirements of a deed.

\section{(b) Benefits of a Specialty}

The benefits of a specialty were, also, not necessarily coterminous with those of a deed since specialty creditors - in the estate of a deceased person - were accorded a priority (this, only concerning debts and deeds can cover things other than debts). Such a benefit has now been abolished. Specialties would seem to have the benefit of a deed re a limitation period ${ }^{85}$ and merger. However, if not deeds, they would not (necessarily) be interpreted the same as deeds. Their benefits in respect of consideration and privity are unclear, although both are likely vis-avis contract debts. ${ }^{86}$

\section{(c) Sealed Instrument}

Regardless of the nature (and continued existence) of a specialty, instruments under seal still exist. For example, a legal document that does not otherwise match the prerequisites for a deed (for example, it does not the 'face value' requirement) would be an instrument under seal. So too, warrants of justices, sub-poenas, a licence under seal to use a patent etc, all of which are not deeds (and not specialties since they do not evidence debts). ${ }^{87}$ Instruments under seal do not, necessarily, have the benefits of a deed or a specialty. ${ }^{88}$

\section{(d) Conclusion}

While the law on deeds is opaque, that on specialities is even more so. However, it would seem clear that analysing specialties or instruments under seal - is not necessary to any great degree or depth since if a deed is abolished, so should they since they are treated as synonymous with a deed today in most instances. Further, if instruments under seal are abolished (or if the seal is abolished) so should all three since deeds, specialties and instruments under seal are linked by the common need for a seal. Thus, further analysis of the intricacies of specialties and instruments under seal is of little benefit.

\section{In conclusion, specialties and sealed instruments - like deeds - should be abolished.}

\section{SEALING LEGAL DOCUMENTS}

In 1971, a legal luminary and member of the House of Lords, Lord Wilberforce stated:

Sealing is a completely fictitious matter...I would have hoped that we might have got rid of that mumbo-jumbo and aligned ourselves with most other civilised countries. ${ }^{89}$

Lord Wilberforce stated this more than 45 years ago. Had the seal been dispensed with in 1971, it would have saved even more complex law being developed with the Law of Property (Miscellaneous Provisions) Act 1989, which legislation further complicated matters. As it is, today, individuals no longer seal as a legal requirement and most legal persons do not do so as a matter of practice. Further, as Lord Wilberforce stated, the seal is now a legal fiction. None needs be attached to the legal document; it is enough if the legal document states 'sealed'.

\footnotetext{
${ }^{83}$ McBain Consideration, n 1, pt 1, pp 63-4 and p 70, n 594 referring to Anon v Anon (1313) per Bereford CJ. See also Ibid, pp 63-4.

${ }^{84}$ See also McBain Deeds, n 1, pt 2, p 10.

${ }^{85}$ See the definition in the Limitation Act 1980, s 8.

${ }^{86}$ The fact that a specialty has a different conflict of laws rule vis-a-vis the situs of debts cannot be regarded as a benefit.

${ }^{87}$ See ns 46-9.

${ }^{88}$ They would, likely, have the benefit of an extended limitation period under the Limitation Act 1980, s 8, being treated as a 'specialty' for such purposes. Not being deeds as such, they would not be interpreted as deeds, nor would the rules of privity vis-à-vis deeds apply. Being sealed, the seal would import consideration. Merger would be of little relevance.

${ }^{89}$ McBain Deeds, n 1, pt 2, pp 12 \& 26. See also Parliament Debate on the Powers of Attorney Act 1971. House of Lords Debates, vol 315, col 1213 (February $25^{\text {th }}, 1971$ ).
} 
Given this, there would seem to be an overwhelming case to accept the reality of the signature and to abolish the sealing of legal documents together with the legal concepts of a deed and a specialty. ${ }^{90}$

\section{(a) Consequences - Individuals \& Corporations Sole}

Individuals no longer seal. ${ }^{91}$ What of corporations sole, however ? For corporations sole, in order to make a deed, the legal document must: (i) satisfy the face value requirement and be; (ii) in writing; (iii) sealed; and (iv) delivered - since no provision was made in the Law of Property (Miscellaneous Provisions) Act 1989 for a signature instead of a seal. ${ }^{92}$

- However, corporations sole are all individuals. They comprise a person and his (or her) successors in some office (or station) who are incorporated in law and they are created by charter or statute. ${ }^{93}$ Thus, the formalities for individuals and corporations sole should be identical including the abolition of the need for a seal;

- As it is, abolishing the seal for corporations sole - and making provision for signing - would not appear to be problematic. There appear to be less than 50 types of corporation sole. They include the Crown, various Secretaries of State (ministers) and various clerics of the Church of England (but not of other religious denominations) ${ }^{94}$ all of whom, in practice, sign anyway and most of whom use wafer seals. ${ }^{95}$

In any case, a corporation sole is not obliged to have its own seal and, if needed, it can use that of another. In 1998, the Law Commission considered that - permitting corporations to execute legal documents without a seal would be useful ${ }^{96}$ as had a legal article in $1991 .^{97}$

In conclusion, the seal should be abolished for corporations sole. ${ }^{98}$ The only exception should relate to where the great seal (or the privy seal) applies in the case of the Crown (see (e)).

\section{(b) Consequences - Corporations Aggregate}

In 1998, the Law Commission considered the abolition of the seal in the context of the Companies Act 1985, s $36 \mathrm{~A} .{ }^{99}$ It listed 4 advantages of execution under the seal, viz.

(i) a seal might offer a 'greater guarantee of authenticity' than execution by the signature of two officers alone;

(ii) a company may make arrangements for the custody (and use) of the common seal which will assist in controlling the obligations it enters into by deed;

(iii) a seal may assist where documents are to be used abroad in a jurisdiction which requires execution under seal;

(iv) a seal can be more flexible than execution by the signature of one or two officers since the company may extend the range of persons authorised to attest the sealing (or dispense with attestation entirely). ${ }^{100}$

However, none of these have weight today, as to:

- (i), a plain seal - or the word 'sealed' - offers less authenticity that the signature of two officers, since the latter can be identified and a graphologist can opine on whether the signatures are authentic;

\footnotetext{
${ }^{90}$ Abolishing the seal removes, ipso facto, the legal concept of an instrument under seal. However, separately abolishing deeds and specialties is needed since both now cover instances where a seal is not used e.g. in the case of an individual, who does not need to seal. Or, in the case of a statutory debt.

${ }^{91}$ Law of Property (Miscellaneous Provisions) Act 1989, s 1(3).

${ }^{92}$ See, generally, McBain Deeds, n 1, pt 1, pp 26-7. See also Halsbury, n 1, vol 32, para 232.

${ }^{93}$ McBain Deeds, n 1, pt 1, p 26.

${ }^{94}$ Ibid. Thus, they include: (a) the Crown; (b) Solicitor to the Duchy of Lancaster; (c) various clerics of the Church of England; (d) Treasury Solicitor; (e) Public Trustee; (f) Official Custodian for Charities; (g) various Secretaries of State (ministers); (h) various Ombudsmen; (i) various Commissioners; (j) various other Officers; (k) Master of Pembroke College, Oxford.

${ }^{95}$ McBain Deeds, n 1, pt 1, p 26.

${ }^{96}$ Ibid, pt 2, pp 11 \& 24.

${ }^{97}$ G Virgo \& C Harpum, Breaking the Seal: The New Law on Deeds (1991) 11 LMCLQ 209, 229 (it proposed that corporations sole should be able to sign as opposed to seal).

${ }^{98}$ See also McBain Deeds, n 1, pt 2, p 11.

${ }^{99}$ See now the Companies Act 2006, sections 43-50. See also Halsbury, n 1, vol 32, paras 240-51.

${ }^{100}$ See McBain Deeds, n 1, pt 2, pp 11-2 \& 25.
} 
- (ii), most off-the-shelf companies are tiny affairs using no seal as such (or, if so, they attach a wafer or put the statement 'sealed');

- (iii), many foreign jurisdictions do not require execution under seal;

- (iv) attestation is not the same as sealing and it can apply to a signature as well as a seal.

As it is, today, most corporations aggregate are not required to have a common seal or legislation permits them to sign as opposed to seal. ${ }^{101}$ Further, common law and statutory presumptions of sealing and due execution seem to (clearly) evidence that legislation - and the English courts - have developed an over-arching principle that a corporation aggregate should not be able avoid legal documents on the basis of its formal requirements for execution. Not least, since they are responsible for them. ${ }^{102}$ Thus, it is asserted that the seal should be abolished. If so, and the signature is employed instead, it needs to be considered whether two - or just one - designated officer is required. The latter may stem from Biblical grounds ${ }^{103}$ and, today, one signature can be used for a foreign corporation where no local law provides otherwise. It is suggested that one signature might be sufficient.

In conclusion - given the above - and the obvious benefits of making the execution requirements for all corporations aggregate the same, any legal document should be formally valid (i.e. treated as duly executed) in the case of a corporation aggregate if signed by one (or two) designated officer(s). Legislation on this should over-ride any prior legislation (general, local or private) or statutory instrument or any corporation aggregate's constitutional documents.

\section{(c) Partnerships}

In the case of a limited liability partnership (LLP), at present, the legal document must make it clear on its face that it is a deed. It must also be sealed with the common seal (or signed by two members of the LLP) and delivered. If the instrument is sealed with the common seal, attestation is required.$^{104}$ It is proposed that - like corporations aggregate - the seal should be abolished and execution by one designated officer should be sufficient. In the case of general partnership, each partner signs as an individual. ${ }^{105}$

\section{(d) County Palatine and Duchy of Lancaster \& Duchy of Cornwall.}

In the case of all three, a deed does not need to make it clear on its face that it is a deed. However, it must be sealed and delivered, save in the case of the duchy of Lancaster where this was never necessary. ${ }^{106}$ It is proposed that, in these instances, the modern practice of signing should be substituted for sealing.

\section{(e) Great Seal \& Privy Seal}

The Crown (sovereign) may execute documents under the great seal. ${ }^{107}$ As to legislation on this matter:

- The Great Seal Act 1688 provides for commissioners of the great seal to supplement the Lord Chancellor. ${ }^{108}$ However, they have been in abeyance since 1836 (and the lord keeper of the great seal since 1761). ${ }^{109}$ Thus, in modern times, it would not seem unreasonable for a Formalities Act to make

\footnotetext{
${ }^{101}$ Ibid, pt 1, pp 27-28. See also Halsbury, n 1, vol 32, paras 240-51.

${ }^{102}$ Ibid, p 28.

${ }^{103}$ The Compact NIV Study Bible(Zondervan Corp, 1985), Book of Deuteronomy, ch 19, v 15 'A matter must be established by the testimony of two or three witnesses'. See also St Matthew, ch 18, v 16. Also, AJ Robertson, The Laws of the Kings of England from Edmund to Henry I (Cambridge UP, 1925), p 35, laws of king Edgar (959-975) in the case of sales 'two or three men who have taken the oath...shall be present as witneses at every transaction.' See also McBain Deeds, $\mathrm{n} 1, \mathrm{pt} 1, \mathrm{p} 21$.

${ }^{104}$ McBain Deeds, n 1, p 17.

${ }^{105}$ Noted in argument by counsel for the claimants in Briggs $v$ Gleeds (2015) 212 at p 215 'The effect of section 1(3)(a)(i) of the Law of Property (Miscellaneous Provisions) Act 1989 is that, in the case of a conventional partnership (i.e. not an LLP), a document will only constitute a deed if (1) it is executed by all the partners (absent a specific arrangement to the contrary, such as one partner being appointed to act as the attorney for the others); and (2) each of them does so in the presence of an attesting witness.'

${ }^{106}$ See also Law of Property (Miscellaneous Provisions) Act 1989 and Coke, n 36, vol 4, p 209 'the grant under the seal of the duchy [of Lancaster] is a matter of record in respect of the dignity of the person on the king, and needeth no delivery to make it a deed.'

${ }^{107}$ See generally McBain, $\mathrm{n} 23$.

${ }^{108}$ The Great Seal Act 1688 provides (commissioners of the Great Seal may execute the power and entitled to the emoluments of Chancellor. Their place).Such Commissioners for the time being may use and exercise at all times according to their Commissions as of right belonging to the Lords Commissioners of the Great Seale of England for the time being all and every the same and like offices authority jurisdiction and execution of laws and all other customes priviledges emoluments and advantages which the Lord Chancellor of England or Lord Keeper of the Great Seale of England for the time being of right ought to have use or execute as belonging to their or either of their said offices or otherwise howsoever to all intents and purposes as if the said Lords Commissioners for the time being were Lord Chancellor or Lord Keeper of the Great Seale of England and shall have and take place next after the peeres of this realme and Speaker of the House of Commons unlesse any of them shall happen to be a peere and then to take place according to his peerage.'

${ }^{109}$ See McBain, n 23, p 446.
} 
provision for Her Majesty to appoint someone in place of the Lord Chancellor if he is absent or incapacitated;

- The Great Seal (Offices) Act 1764 provides for the office of the clerk of the great seal ${ }^{110}$ and his fees. ${ }^{111}$ The other sections of this Act are spent and it would not seem necessary for these to be in legislation today.

The Great Seal Act 1884 provides for the passing of an instrument under the Great Seal, viz.

A warrant under Her Majesty's Royal Sign Manual, countersigned by the Lord Chancellor, or by one of Her Majesty's Principal Secretaries of State, or by the Lord High Treasurer, or two of the Commissioners of Her Majesty's Treasury, shall be a necessary and sufficient authority for passing any instrument under the Great Seal of the [UK], according to the tenor of such warrant; provided that any instrument which may now be passed under the Great Seal by the fiat or under the authority or directions of the Lord Chancellor or otherwise without passing through any other office may continue to be passed as heretofore. ${ }^{112}$

The wording in italics would seem otiose, today. The Crown Office Act 1877 provides for the great and privy seals to be in a wafer form, viz.

A Committee of Her Majesty's Most Honourable Privy Council, consisting of the Lord Chancellor of Great Britain for the time being, the Lord Privy Seal for the time being, and one of Her Majesty's Principal Secretaries of State (in this Act referred to as the Committee of Council), acting in case of difference according to the opinion of any two of them, may from time to time direct impressions with the same device as the Great Seal and of the Privy Seal to be taken in such manner and of such size or sizes as they may from time to time prescribe, on embossed paper, wax, wafer, or any other material; and any such impressions, in this Act respectively called a Wafer Great Seal and a Wafer Privy Seal, shall be in the same custody as the seals of which they are impressions, and when attached to or embossed on any document required to be or usually authenticated by or passed under the Great Seal or Privy Seal, they shall confer on that document the same validity in all respects as if the document itself had been authenticated by or passed under the Great Seal or Privy Seal. ${ }^{113}$

It is asserted that all these pieces of legislation should be repealed and a modern formulation of them should be inserted into a Formalities Act (including all of the Crown Office Act 1877), see Appendix A.

In conclusion, sealing should be abolished and the signature employed for corporations sole and aggregate - as well as other legal persons - with execution by one designated officer (or, at most, two) being a sufficient formal prerequisite.

\footnotetext{
${ }^{110}$ Section 8, 'It shall continue to be lawful for Her Majesty from time to time under Her Royal Sign Manual to appoint a fit person to fill the office of clerk of the Crown in Chancery. The clerk of the Crown in Chancery shall continue to perform the duties of the office of keeper or clerk of the hanaper... There shall be paid to any person appointed ...to be clerk of the Crown in Chancery such salary as the Treasury may assign to him. The salaries of the clerk of the Crown in Chancery, and of his officers, and the expenses of his office, shall be paid out of moneys provided by Parliament.'

${ }^{111}$ Section 9, 'The Lord Chancellor, with the concurrence of the Treasury, may from time to time by order appoint the fees to be taken in the office of or by the clerk of the Crown in Chancery, or by any of his officers, or by any person performing the duties of messenger or pursuivant of the Great Seal, or gentleman of the chamber attending the Great Seal, or purse-bearer to the Lord Chancellor, or chaff wax sealer or deputy sealer, and may from time to time by order increase, reduce, add to, or abolish the fees for the time being taken in such office or by such officer...No fees other than those so appointed shall be taken in the said office or by any of the above mentioned officers or persons.'

${ }^{112}$ Section 2(2), 'The Lord Chancellor may from time to time make, and when made revoke and vary, regulations respecting the passing of instruments under the Great Seal of the [UK], and respecting the warrants for that purpose, and the preparation of such instruments and warrants, and every such warrant shall be prepared by the Clerk of the Crown in Chancery. (3) No person shall make or prepare any warrant for passing any instrument under the Great Seal of the [UK], or procure any instrument to be passed under that Seal otherwise than in manner provided by this Act or the Crown Office Act 1877; and any person who acts in contravention of this section shall be guilty of a misdemeanour.' One would suggest that the criminal offence in (3) (for which no penalty is provided) is no longer required.

${ }^{113}$ See s 4. Also, s 5 which provides for rules to be made as to the wafer seal: "The Committee of Council aforesaid, acting in case of difference according to the opinion of any two of them, may by order make, and when made from time to time revoke, add to, or alter rules (2) prescribing the documents to which the Wafer Great Seal and the Wafer Privy Seal respectively are to be attached; and (3) prescribing the mode in which documents to which this Act applies are to be prepared, whether to be printed or written, or partly printed and partly written, and whether to be printed or written on paper, parchment, or any other fitting material: provided that (a) it shall not be necessary to the validity of any document to or on which a Wafer Great Seal or Wafer Privy Seal is attached or embossed to prove that the attachment or embossing of such wafer seals respectively was authorised and no evidence to the contrary shall be received....(c) Any rule purporting to be made in pursuance of this section shall be laid before both Houses of Parliament.' Section 3(b) is spent.'
} 


\section{CONCLUSION - DEEDS, SPECIALTIES \& SEALS}

Deeds, specialties and seals should be abolished, in order to recognise the supremacy of the signature. Further, the methods by which legal documents are validly executed should be set out in a Formalities Act, something the London Law Society advocated in 1998 (one could not have put it better):

We strongly support the insertion of any relevant new legislation into a single set of statutory provisions which can easily be referred to and understood by the legal profession. ${ }^{114}$

Further, this should not be difficult, see Appendix A. As well as deeds, specialties and seals, other formal requirements for the execution of a legal document should also be dealt with in a Formalities Act. These are now considered.

\section{POWERS OF ATTORNEY}

At present, powers of attorney are regulated by the Powers of Attorney Act 1971. This Act was amended by the Law of Property (Miscellaneous Provisions) Act 1989 to require a power of attorney to be by way of deed. ${ }^{115}$ If deeds are abolished, such will no longer apply and the rather confusing wording in the Powers of Attorney Act 1971 should be re-stated. Given that other sections of this Act are spent - it would be of great utility to lawyers (and to others) if a Formalities Act were to re-state the Powers of Attorney 1971 as well as to consolidate it with the Powers of Attorney (Northern Ireland) Act 1971 and the Evidence and Powers of Attorney Act 1940.

In conclusion, all legislation on powers of attorney (except enduring powers of attorney) should be placed in a Formalities Act.

\section{NOTARISATION}

\section{(a) Activities of a Notary}

Unlike in civil law systems, notarising legal documents is uncommon in England and Wales. ${ }^{116}$ This formality is (usually) only employed when it is needed for foreign purposes. Or, when legislation requires it. It seems there are no instances where the common law mandates notarisation. This, probably, results from a general distrust of the civil law which the common law has long retained. ${ }^{117}$ Brooke's Notary lists the principal matters in which notaries in England and Wales tend to be involved, viz.
(a) verifying documents to take abroad; ${ }^{118}$
(b) preparing (and translating) documents for use abroad;
(c) translating documents from abroad;
(d) protesting bills of exchange;
(e) certifying copies (i.e. authenticating true copies of original documents);
(f) conveyancing and wills;
(g) statutory declarations and affidavits;
(h) ships' protests;
(i) certificates of law;
(j) drawing bonds etc.;

(k) witnessing the destruction of redeemed bonds, the breaking of seals on goods etc.

However, many of these activities have been taken over by law firms or they are (effectively) obsolete especially those referred to in italics. ${ }^{119}$

\footnotetext{
${ }^{114}$ McBain Deeds, n 1, pt 1, p 15.

${ }^{115}$ Powers of Attorney Act 1971, s 1 'An instrument creating a power of attorney shall be executed as a deed by the donor of the power... (3) This section is without prejudice to any requirement in, or having effect under, any other Act as to the witnessing of instruments creating powers of attorney and does not affect the rules relating to the execution of instruments by bodies corporate.' This wording is opaque.

${ }^{116}$ See generally, McBain Notaries, n 1. The only modern specialised text on notaries is Brooke's Notary, see n 21. For the history of notaries from Roman times, see Ars Notariatus (1740), n 1, pp 1-15 and in Scotland, pp 1644.

${ }^{117}$ McBain Notaries, n 1, p 91.

${ }^{118}$ Ibid, p 92. Brooke's Notary, n 1, p 23 described this as the 'principal feature of a notary's practice'.

${ }^{119}$ Thus, as to (h), notaries are involved in the noting, and drawing up, of ships' protests. Also, protests relating to demurrage and other commercial matters. However, such protests, today, are much more rare, as is notarial involvement. In the case of ( $j$ ), foreign governments (and institutions), often, make loans containing an option to redeem all (or part) of the loan prior to maturity. Sometimes, the redemption is by lot and, sometimes, the terms of such stipulate the presence of a notary as a disinterested party. However, today, the process is (invariably)
} 


\section{(b) Statutory Requirements for Notarisation}

The only statutory requirement for notarisation (it seems) is the Bills of Exchange Act 1882 (the 'BEA 1882') which codified the law on bills of exchange. ${ }^{120}$ The BEA 1882 distinguishes between inland ${ }^{121}$ and foreign bills. The former is effectively obsolete - save as to cheques $-{ }^{122}$ and inland bills should be abolished (apart from in the case of cheques). That is, persons should be prevented from creating inland bills of exchange. As it is, a bill which is not an inland bill is categorised as a foreign bill. Brooke's Notary observes:

A foreign bill differs from an inland bill in the respect that if dishonoured it must be protested, whereas a dishonoured inland bill generally needs no protest in order for an action to be founded on it. ${ }^{123}$

When a foreign bill is dis-honoured by non acceptance - or non payment - the holder of the bill acquires a right of action against the drawer of the bill as well as any indorser(s). However, for the right to be enforceable, not only must notice of dishonour be given, for a foreign bill, it must be protested. Notice of dishonour is a formal notice. This is subject to exceptions, ${ }^{124}$ dispensations ${ }^{125}$ and exemptions. ${ }^{126}$ As for protesting, a component of this is noting the same. ${ }^{127}$ The protest is a formal procedure, as described in Brooke's Notary:

In order for this to be done it must be taken to a notary who, at a reasonable hour of the day on which it is dishonoured, or the next succeeding business day, will, having first made an exact copy of the bill, present it a second time to the drawee (in the case of a protest for non-acceptance) or to the person designated by the bill as payer at the proper place as determined by the [BEA 1882] (in the case of protest for non-payment) and make a formal demand for its acceptance or payment, as the case may be. ${ }^{128}$

However, this protest procedure is, often, short circuited (that is, speeded up) by the notary not presenting for acceptance (or payment) a second time where dishonour is otherwise certain. ${ }^{129}$ Further, there is no prescribed form of protest. Also, protest is not required in any situation where a notice of dishonour is not required. ${ }^{130}$

- It is also possible to protest a bill (whether foreign or inland) for better security where the acceptor of a bill becomes bankrupt or insolvent or it suspends payment before the bill matures. ${ }^{131}$ However, such is rare (the expenses of the protest being irrecoverable and protest for better security not being a legal requirement, even in the case of a foreign bill);

\footnotetext{
a computerised one and a notary is not involved. See McBain, $n$ 1, p 93. So too, in respect of debenture stock and share ballots. Ibid, p 94. In the case of $(k)$, the presence of a notary is also uncommon today.

${ }^{120}$ Bills of exchange, which probably originated in Italy in the $12^{\text {th }}$ century (if not earlier), enable debts to be settled by means of a piece of paper. A bill of exchange which satisfies the prerequisites of the Bills of Exchange Act 1882 is legally enforceable. One of the benefits of the bill of exchange is that it is negotiable. Thus, the debt represented by the bill can be transferred.

${ }^{121}$ Inland bills comprise those which are (or which purport to be) drawn and payable in the British Islands or which are drawn in the British islands on a person resident there. British islands means any part of the UK including the Isle of Man, Guernsey, Jersey, Aldernay and Sark and the islands adjacent to any of them, being part of the dominions of Her Majesty. See McBain Notaries, n 1, p 96 and BEA 1882 , s 4.

${ }^{122}$ Inland bills drawn by individuals and legal persons were displaced by cheques (i.e. inland bills drawn on a bank) and, in the $20^{\text {th }}$ century, by electronic payment systems which are much cheaper, faster, less legally complex and less susceptible to fraud. Doubtless, cheques will also, soon, become obsolete (or will be abolished as a payment mechanism) for the same reason.

${ }^{123}$ McBain Notaries, n 1, p 96 referring to Brooke's Notary, n 21, p 113 (emphasis added). In fact, inland bills were not legally required to be protested and they were (and are) not, in practice. The BEA 1882 placed in legislation protest at common law, which also existed in Scotland, see Ars Notariatus (1740), n 1, pp 241-2.

${ }^{124}$ If the bill is dis-honoured it is unnecessary to give notice of a subsequent refusal by non-payment, unless the bill has been accepted in the meantime. McBain Notaries, n 1, p 97.

${ }^{125}$ It is not required: (a) when, after the exercise of reasonable diligence, it cannot be given to (or does not reach) the party to be charged; or (b) it has been expressly (or impliedly) waived by the party entitled to it (i.e. the defaulter). McBain Notaries, n 1, p 97.

${ }^{126}$ Notice of dishonor vis-à-vis the drawer of a bill is unnecessary when: (i) the drawer and drawee are the same person; (ii) the drawee is fictitious or a person lacking the capacity to contract; (iii) the drawer is a person to whom the bill is presented for payment; or (iv) the drawee (or acceptor) is, as between himself and the drawer, under no obligation to accept (or pay) the bill; or (v) the drawer has countermanded payment. See McBain Notaries, n 1, p 97.

${ }^{127}$ The noting of the bill is the making of a note (or minute) on the face of the bill, this comprising: (i) the notary's initials; (ii) the date of noting; (iii) the noting charges; and (iv) a reference to a mark (or number) in the notary's register in which the notary records all bills (and promissory notes) which he has noted.

${ }^{128}$ McBain Notaries, n 1, p 99.

${ }^{129}$ As Brooke's Notary notes, if a holder of a bill is sure it will be dishonoured - to save time and money - instead of the bill being formally presented for acceptance (or payment) the notary will ignore this and present the bill in the ordinary way. If dishonoured (rejected) he will then re-present it notarially. See McBain, n 1, p 99.

${ }^{130}$ McBain, n 1, p 100.

${ }^{131}$ Ibid, p 101. See also BEA s 51(5).
} 
- Finally, it is possible for there to be acceptance and payment for honour supra protest. This, where a third party agrees - after the protest of a foreign (or an inland) bill - to step in to accept liability on the bill in place of the defaulter, after protest. This is also (very) rare, since third parties, generally, do not want to guarantee the credit of others in such a situation. ${ }^{132}$

In conclusion, foreign (but not inland) bills of exchange must be noted and protested.

\section{(c) Abolishing Noting \& Protest - Foreign Bills}

The noting and protest of a foreign bill is an arcane and administratively time consuming procedure (as well as incurring notarial fees) in the nature of a 'blast from the past'. It had some purpose in medieval Italian times, ${ }^{133}$ when it was designed to embarrass a party into paying up. As Brooke's Notary states:

The origin of protesting dishonoured bills lies in medieval Italian commercial practice. The dishonoured bill was taken to the house of the merchant who failed to honour his commitments and, as his door was knocked, a protest was made publicly about the defaulter's miscreance. ${ }^{134}$

Thus, there was - in early times - no legal purpose to the noting and protest of a foreign bill. Rather, it was a process of naming and shaming a person (an individual) into paying his debt since his social and commercial creditworthiness were publicly impugned. Today, this rationale has gone. Today, foreign bills are drawn (if at all) by legal persons in large offices without neighbours to be interested in their credit. There are other reasons why this requirement for foreign bills should be dispensed with:

- Inland Bills. Noting and protest is not legally required in the case of inland bills (and was rare in practice, anyway) and this has never had an adverse effect;

- $\quad$ Promissory Notes \& Cheques. The BEA 1882 has never required noting in the case of promissory notes (whether inland or foreign). Nor in the case of cheques - since they are, invariably, treated as (or are) inland bills. ${ }^{135}$ Nor, in practice, are the same (i.e. promissory notes and cheques) noted or protested;

- Noting \& Protest - Foreign Bills. Noting and protest is not required where a notice of dishonour is not required and the latter is subject to various exceptions, dispensations and exemptions (see $(b)$ ). Further, noting and protest is only required where the foreign bill appears to be such on its face. However, this is rare for cheques and for many bills that would, otherwise, be treated as foreign bills; ${ }^{136}$

- Volume of Foreign Bills. This is much less than in the past, given faster and more efficient payment methods. Thus, the need to note and protest has declined and such, anyway, is rare - most foreign bills being honoured in practice. Acceptance and payment supra protest are also (very) rare and, thus, noting and protesting against a third party who does not pay up, is also (very) rare;

- $\quad$ No Legal Benefit of Noting \& Protesting. Although required by the BEA 1882 for foreign bills, noting and protest does not, actually, accord any additional benefit to a holder vis- $a$-vis the defaulter;

- $\quad$ Legal Detriment of not Noting. A holder who fails to note and protest a foreign bill incurs real legal detriment in that it cannot, then, enforce the bill against the drawer (or any indorser). ${ }^{137}$ This is draconian - especially when noting and protesting are not required for any legal reason as such - but, rather, it is a practical remedy (of trying to enforce payment by publicly embarrassing a person into it). Today, it is asserted that it is an unjust legal formalism to compulsorily require noting and protest since the result may be to negate the debt when the creditor fails to perform a formal requirement that no longer has a purposive element. One, additionally, which was intended for its benefit. Thus, the compulsory requirement of noting and protest can (at times) wholly prejudice the very party whom this process was designed to assist - the creditor (the holder of the bill).

\footnotetext{
${ }^{132}$ See BEA 1882, ss 65 \& 68. See also McBain, n 1, pp 101-2.

${ }^{133}$ Likely, the concept of bills of exchange arrived in England from Italian practices. Kings such as Edward I (1272-1307), Edward II (130727) and Edward III (1327-77) depended heavily on Italian financiers after Jewish people were expelled from England in 1290.

${ }^{134}$ McBain, n 1, p 99.

${ }^{135}$ As noted in Ellinger's, Modern Banking Law (2011), pp 421-42 'In practice... 'noting' and 'protesting' a cheque should rarely arise as the vast majority of cheques are drawn by UK residents on UK banks and accordingly are 'inland bills', even if the payee happens to reside abroad.' Also, cheques are not presented for acceptance but for payment.Thus, noting and protest for the former do not occur anyway. McBain, n 1, p 103.

${ }^{136}$ See McBain, n 1, p 104 fn 82 referring to Elllinger, see n 135 'unless there is some indication on the face of the cheque that it is a 'foreign bill' (such as an indication that it was drawn abroad), then the holder is entitled to treat the cheque as an 'inland bill'.

${ }^{137}$ BEA 1882, s 51(2) 'if it be not so protested the drawer and indorsers are discharged.'
} 
The Jack Committee Report on Banking Services in 1989 recommended that compulsory noting and protest be abolished but that it be possible to make a voluntary protest via the issue of a simple certificate of the facts given by anyone entitled to take an oath - and not just notaries. ${ }^{138}$ This was supported by a Government White Paper in $1990{ }^{139}$ It should be observed, however, that the Jack Committee's Report and the Government White Paper were predicated on the notion that the Uncitral Convention 1988 (which provided for mandatory protest) would come in force in England and Wales. ${ }^{140}$ This has not occurred since this Convention is not in force. In any case, the UK is not a signatory to this Convention. ${ }^{141}$ More particularly, both the Report and the White Paper stated that:

Noting and protest...is, under the [BEA 1882], required only for a foreign bill, because some courts overseas will not accept that the bill has [otherwise] been dishonoured either by non-acceptance or nonpayment. $^{142}$

This is incorrect since the noting and protest of a foreign bill was not due to this under English law. Rather, it was the adoption of the Italian medieval practice of embarrassing a party into payment. ${ }^{143}$ Further, in any case, parties could (if mandatory noting and protest, as required by the BEA 1882, was abolished) provide evidence to a foreign court (if needed) of the bill being dishonoured by way of a notarised certificate of demand or such other form that would satisfy the relevant local law.

\section{(d) Conclusion}

The only statutory provision in legislation for the formality of notarisation appears to be contained in the BEA 1882. This, in respect of the noting and protest of foreign bills. If the relevant sections of the BEA 1882 re noting and protest were repealed as unnecessary - as well as those relating to protest for better security and acceptance (or payment) for honour supra protest - no distinction between inland and foreign bills is required (albeit, inland bills should also be abolished, save for cheques). More importantly, repeal of these sections of the BEA 1882 will help clarify when notarisation is required under English law.

In conclusion, a Formalities Act should abolish any common law requirement for notarisation (although there would appear to be none anyway). Sections of the BEA 1882 relating to noting and protest (as well as to acceptance and payment for honour supra protest) should be repealed.

\section{LEGALISATION (CONSULARISATION)}

Legalisation is also, sometimes, called 'consularisation 'or 'apostillization.' ${ }^{144}$ This comprises a formality in which the diplomatic (or consular) agent of the country in which a legal document is produced, certifies:

- the authenticity of the signature on the legal document;

- the capacity in which the person signing the legal document has acted;

- (where appropriate) the identity of the seal (or stamp) it bears.

The above is stated in the Hague Convention of 5 October 1961 (the 'Hague Convention'), article 2, which Convention the UK has ratified.

- The Hague Convention abolished the requirement for the legalisation of public documents (which are defined to include notarial acts) executed in the territory of one Contracting State (which includes the UK) and required to be produced in the territory of another Contracting State;

\footnotetext{
${ }^{138}$ McBain, n 1, p 106.

${ }^{139}$ White Paper, 'Banking Services: Law and Practice (March, 1990), Cm 1026, Annex 6, paras 6.6. \& 6.7 'Noting and protest are procedures for providing formal proof that a bill of exchange has been presented and dishonoured. Protesting is mandatory under the 1882 Act for foreign bills because some overseas courts will not otherwise accept that a bill has been dishonoured. The Government proposes to abolish the mandatory requirement for noting and protesting a dishonoured foreign bill. However, this procedure would be retained in a slightly modified form for use on a voluntary basis. Anyone entitled to take an oath would be able to give a simple certificate of the facts in order to fulfil the requirements in those countries where noting and protesting are still required.'

${ }^{140}$ UN Convention on International Bills of Exchange and International Promissory Notes 1988, arts 60-3 relate to protest and art 60(3) relates to a declaration.

${ }^{141}$ Only Gabon, Guinea, Honduras, Liberia and Mexico have acceded to it to date.

${ }^{142}$ McBain Notaries, n 1, p 106.

${ }^{143}$ See text to $\mathrm{n} 134$.

${ }^{144}$ The word 'apostillization' only applies where the Hague Convention 1961 applies. However, it is possible for the British consulate to issue a certificate where the Hague Convention does not apply. Thus, 'consularization' tends to be used here. Although 'legalisation' was replaced by the apostille, the word is still in common use to (generically) refer to any consular certification, whether under the Hague Convention or not.
} 
- Pursuant to this Convention, 'legalisation' was replaced by a simpler process of adding to the document a certificate (called an 'apostille') issued by the competent authority of the State from which the document emanated.

Only documents issued by a public notary (or some other public official) from the country from which the document derives are capable of being legalised. However, some embassies (or consulates) are prepared to append legalisations to private signatures. The Convention does not impose a requirement of legalisation where it does not otherwise exist. ${ }^{145}$ Brooke's Notary states:

Legalisation is rarely necessary in the case of documents executed in the United Kingdom and intended for use in a Commonwealth country, but is a frequent requirement if the document is to be used elsewhere. ${ }^{146}$

However, the Hague Convention does not require legalisation where English legislation does not otherwise require. As it is, this process of legalisation/consularisation is relatively clear. Thus, it is asserted that no provision as to its modernisation need be made in a Formalities Act.

In conclusion, legalisation (consularisation, apostillization) does not need not to be dealt with in a Formalities Act.

\section{ATTESTATION}

\section{(a) Nature of Attestation}

Attestation is a formal requirement. It is not the same as witnessing, since (as the concept is understood in modern times) attestation requires the person witnessing to also be physically present when the document was executed. Attestation means a witness signs a legal document following a statement (an attestation clause) that the legal document was signed, or executed, by the maker in his presence. Thus, in Wickham v Marquis of Bath (1865), ${ }^{147}$ Romilly MR stated that attestation meant that:

one or more persons are present at the time of the execution for that purpose and that as evidence thereof they sign the attestation clause, stating such execution. ${ }^{148}$

The witness must see the maker sign the instrument. ${ }^{149}$

\section{(b) Legal Requirement of Attestation}

In Anglo-Saxon and Norman times, charters (deeds) were executed in the presence of a number of witnesses. They did not sign the document, however, although there was a form of 'attestation clause' ${ }^{150}$ Since this was without the signature of the witness it was not the same as the modern concept of attestation. From the time of Henry VIII (1509-47), witnesses tended, in practice, to sign at the bottom (or on the back) of the deed - the deed being the prevailing form of legal document. ${ }^{151}$

- Attestation was not a common law prerequisite for a deed however - although, in practice, many deeds were attested. ${ }^{152}$ Thus, for a deed, attestation was not required until the Law of Property (Miscellaneous Provisions) Act 1989. This provided that a legal document was only validly executed as a deed by an individual if signed by him in the presence of a witness who attested his signature (or at his direction and in his presence and the presence of two witnesses who each attested his signature);

\footnotetext{
${ }^{145}$ Ready, n 21, pp 244-5 'It is important to note that the Convention does not introduce a requirement for the affixing of an apostille where no requirement for legalization would otherwise exist. Thus, although many Commonwealth countries are parties to the Convention, it is rarely necessary that a public document issued in the [UK] for use in such a country will require the addition of an apostille, since the courts in most Commonwealth countries take judicial notice of the signatures and seals of notaries public and officials in the [UK]. It should also be noted that the embassies and consulates of a number of countries continue to provide legalization services notwithstanding that the Convention is in force in those countries. The validity of such legalizations is not affected by the Convention.'

${ }^{146} \mathrm{Ibid}, \mathrm{p} 244$.

${ }^{147}$ (1865) LR 1 Eq 17.

${ }^{148}$ At $\mathrm{p} 24$. See also McBain Deeds, n 1, pt 1, p 53

${ }^{149}$ See also McBain Deeds, n 1, pt 1, p 53.

${ }^{150}$ It was 'hiis testibus' ('these being witnesses'). See McBain Deeds, n 1, pt 1, pp 23-4.

${ }^{151}$ Blackstone, n 13, vol 2, p 308 who noted that the reign of Henry VIII was also the era of 'discontinuing it [i.e. the hiis testibus clause] in the deeds of subjects, learning being then revived, and the faculty of writing more general; and therefore ever since that time the witnesses have subscribed their attestation, either at the bottom, or on the back, of the deed.' See also McBain Deeds, n 1, pt 1, pp 23-4.

${ }^{152}$ See McBain Deeds, n 1, pt 1, p 30.
} 
- In 1989, the Powers of Attorney Act 1971 was amended to require a power of attorney to be in the form of a deed. Thus, attestation was also required in the case of an individual making the same. ${ }^{153}$

As for legislation, the first legislation requiring attestation was the Statute of Frauds 1677, requiring wills to be attested ${ }^{154}$ (see also, later, the present Wills Act 1837, s 9). ${ }^{155}$ From the Victorian era, provision was made for attestation and a variety of pieces of legislation and statutory instruments today refer to need to attest various documents. ${ }^{156}$ In the case of attestation by corporations aggregate, in the case where a legal document is sealed, it may be asserted that the witnesses who sign the legal document, as such, are not attesting the seal (i.e. attesting the execution of the document by the attachment of the seal in their presence). Rather, they are 'authenticating' the seal. ${ }^{157}$

\section{(c) Problems with Attestation}

Legislation making attestation a legal requirement has introduced a (considerable) problem where there was none before.

- When the Law of Property (Miscellaneous Provisions) Act 1989 introduced, as a substantive requirement (a prerequisite), attestation in order for an individual to execute a deed, the Law Commission recommended this on the basis of 4 arguments: viz. (i) it would distinguish deeds from mere signed documents; (ii) it would emphasise to the person executing the importance of his act; (iii) it would give rise to an evidential presumption of due execution; (iv) it might assist in the prevention or (at least) the detection, of forgery; ${ }^{158}$

- However, (i) and (ii), relate to deeds (and they fall by the wayside if deeds are abolished). As to (iii), such a presumption was never enacted. As to (iv), there is no evidence that attestation thwarts this. If persons are determined to forge documents - such as deeds, wills and powers of attorney -they can (easily) forge the signatures of people attesting (or witnessing, for that matter) the same or they can get dishonest attestators (or witnesses) to assist. Further, attestation can have the effect of invalidating a legal document on the basis of a technical formality, in circumstances where this is, often, unjust.

In the case of Shah $v$ Shah (1982), ${ }^{159}$ the Court of Appeal was not prepared to invalidate a document even though it had not been attested. Here, a signature by an individual to a deed was witnessed by a person but not attested, since that person was not physically present when the individual executed the deed, as required by the Law of Property (Miscellaneous Provisions) Act 1989. The Court of Appeal rejected the contention that the deed was, thereby, rendered invalid and held that the signatory was estopped from so asserting. Pill LJ stated:

The perceived need for formality in the case of a deed requires a signature and a document cannot be a deed in the absence of a signature. I can detect no social policy which requires the person attesting the signature to be present when the document is signed. The attestation is at one stage removed from the imperative out of which the need for formality arises. It is not fundamental to the public interest, which is in the requirement for a signature. Failure to comply with the additional formality of attestation should not in itself prevent a party into whose possession an apparently valid deed has come from alleging that the signatory should not be permitted to rely on the absence of attestation in his presence. It should not permit a person to escape the consequences of an apparently valid deed he has signed,

\footnotetext{
${ }^{153}$ The amendment was made by the Law of Property (Miscellaneous Provisions) Act 1989 to the Powers of Attorney Act 1971.

${ }^{154}$ Statute of Frauds 1677 (19 Car 2 c 3), s 6 'in the presence of three or four witnesses, declaring the same.'

${ }^{155}$ Section 9 provides, 'No will shall be valid unless - (a) it is in writing, and signed by the testator, or by some other person in his presence and by his direction; and (b) it appears that the testator intended by his signature to give effect to the will; and (c) the signature is made or acknowledged by the testator in the presence of two or more witnesses present at the same time; and (d) each witness either - (i) attests and signs the will; or (ii) acknowledges his signature, in the presence of the testator (but not necessarily in the presence of any other witness), but no form of attestation shall be necessary.'

${ }^{156}$ For pieces of legislation requiring it in Victorian times see JP Taylor, A Treatise on the Law of Evidence (1878), paras 1840-1 and McBain Deeds, n 1, pt 1, p 54, n 444. As to those pieces of general legislation and SI that require attestation today, these may be determined by conducting a wordsearch in the Government's Statute Law Database (www.legislation.giv.uk) as well as from the commercial legislation databases of publishers such as Butterworths (LexisNexis), Thompson Reuters (Westlaw), Hein Online etc. A wordsearch of the word 'attest' refers to some 200 general statutes or statutory instruments. However, in a number of these, the word 'attest' is not a reference to the legal formality of attestation. Given their prevalence though, it would be useful for a Formalities Act to cancel all requirements for attestation from all legislation (general, local and private) as well as from all constitutional documents and internal regulations of all corporations aggregate in respect of legal documents. See Appendix A

${ }^{157}$ See McBain Deeds, n 1, pt 1, pp 30 \& 54.

${ }^{158}$ Ibid, pt 2, pp $12 \& 26$. See also the purposes for the formalities for the execution of legal documents in 2, viz, to (i) prevent fraud; (ii) to help evidence a transaction; and (iii) to require parties to consider the terms of the legal document before executing it.

${ }^{159}$ [2002] QB 35. See also McBain Deeds, n 1, pt 2, pp 12 \& 26.
} 
representing that he has done so in the presence of an attesting witness, merely by claiming that in fact the attesting witness was not present at the time of the signature. The fact that the requirements are partly for the protection of the signatory makes it less likely that Parliament intended that the need for them could in all circumstances be used to defeat the claim of another party.

Having regard to the purposes for which deeds are used and indeed, in some cases required, and the long term obligations which deeds will often create, there are policy reasons for not permitting a party to escape his obligations under the deed by reason of a defect, however minor, in the way his signature was attested. The possible adverse consequences if a signatory could, months or years later, disclaim liability upon a purported deed, which he had signed and delivered, on the mere ground that his signature had not been attested in his presence, are obvious. The lack of proper attestation will be peculiarly within the knowledge of the signatory and, as Sir Christopher Slade observed in the course of argument, will often not be within the knowledge of the other parties. ${ }^{160}$

This reasoning seems (eminently) sensible and it is likely the same reason why judges in earlier times did not make the attestation of a deed a prerequisite. It would have meant that parties could deliberately not have attested deeds (or have attested them defectively) in order to invalidate the deed later. ${ }^{161}$ This case shows that attestation should not be required by statute unless there are very good reasons for it.

\section{(d) Case of Briggs (2015)}

The further problem with attestation may be seen in the case of Briggs and others $v$ Gleeds (Head Office)(a firm) and Others (2015). ${ }^{162}$ Here, an individual signed the deed. However, there was no attestation at all as required by the Law of Property (Miscellaneous Provisions) Act 1989. In this case Newey J distinguished Shah v Shah (1982) on the basis that - in that case - the deeds were 'apparently valid' since a person had subsequently added their name to the deed, to witness the maker's signature (but had not been present when the maker had signed and, thus, had not attested). Thus, estoppel was appropriate, but not where there was no attestation at all (Newey J thought Pill LJ would have come to the same conclusion). ${ }^{163}$ The problem with both Shah (1982) and Briggs (2015) is that they draw ever more nuanced distinctions on the theme of 'what is attestation'? If witnessed it is if the witness is not physically present but, later, signs. ${ }^{164}$ But, if not even witnessed (or, possibly, if the witness is present but does not sign), it is not. ${ }^{165}$ Indeed, Newey $\mathrm{J}$, himself may have been confused as to the difference between attestation and witnessing since - in his judgment - he referred to witnessing when he meant attestation. ${ }^{166}$ Also, Briggs (2015) gives rise to some curiosities:

- In this case, even if not deeds, the relevant legal documents were signed and, thus, instruments under hand, which do not need to be attested. ${ }^{167}$ Thus, it seems that they were enforceable as instruments under hand. Also, at least, some of the relevant legal documents were stated to be sealed by the makers of the same (who were various partners). ${ }^{168}$ Thus, even if not deeds, they could have been specialities (assuming that a specialty is not, now, a synonym for a deed) and enforced as such. Further, if not specialities (which seems, may be limited to debt obligations), they could have been instruments under seal, and enforced as such. These issues were (it seems) not explored in this case;

- The fact that a legal document declares itself to be a 'deed' does not, in law, make it such since this is a matter for a court to conclude as a proposition of law. ${ }^{169}$ Therefore, the fact that, in this case, the legal documents declared themselves to be deeds is not conclusive and a court can hold that they were, in fact, something else.

\footnotetext{
${ }^{160}$ See also McBain Deeds, n 1, pt 2, pp 12-13.

${ }^{161} \mathrm{Ibid}, \mathrm{p} 13$.

${ }^{162}$ [2015] Ch 212.

${ }^{163}$ Ibid, p 231.

${ }^{164}$ What if the witness had been present when the maker signed, but had not signed ? Would that have fallen within Shah (1982) or Briggs (2015) ? What if the documents had declared that they were 'signed, sealed, attested and delivered'?

${ }^{165}$ Cf. L Wittgenstein, Philosophical Investigations (Oxford, 1928), p 82e (proposition 203) 'Language is a labyrinth of paths. You approach from one side and know your way about; you approach the same place from another side and no longer know your way about.'

${ }^{166}$ See e.g. Ibid, p 222 (para 6) 'none of these signatures [of the partners] was witnessed'. Ibid, p 223 (para 8) 'the draft documents...made provision for trustees' signatures, but not those of Gleed's partners, to be witnessed.' In both cases, Newey J meant attestation.

${ }^{167}$ Halsbury, n 1, vol 32, para 356 'In general, attestation is not required for an instrument under hand.'

${ }^{168}$ [2015] Ch 212, 222 para 6, 'stated to be signed sealed and delivered'.

${ }^{169}$ See n 61 .
} 
Another problem is that a convicted forger or a child of five or a beneficiary of a deed, can all attest. Further, no attestation clause, as such, is generally required. Thus, all a party needs to do, in most instances, is to be present at the execution of the legal document as a witness and write their name on the legal document.

What should be done as to attestation? It is asserted that this formality is unduly onerous as a compulsory legal requirement since it is a technicality that might invalidate an otherwise perfectly valid legal document. Thus, witnessing (if at all) is to be preferred. As a result, any requirement at common law - as well as in legislation (also, in any constitutional document) - to attest a legal document should be abolished, including in the case of wills. Obviously, people will continue to attest, in practice, which is fine. However, this should not be a compulsory legal requirement. In conclusion, any legal requirement to attest a legal document at common law or in legislation, should be abolished.

\section{WITNESSING}

\section{(a) Practice of Witnessing until 1677}

From Biblical times, the witnessing of commercial transactions - especially the delivery of land and goods by way of sale, exchange (barter), gift and pledge - was an integral part of the transaction. Since most people were illiterate, they did not attest by attaching their signature. In Anglo-Saxon times, charters/deeds were executed in the presence of a number of witnesses who did not sign the instrument but were recorded as such, their names being subscribed to the charter (hiis testibus). ${ }^{170}$ After the Norman Conquest third parties were, often, called to witness the delivery of seisin or the delivery of the deed and Bracton (c. 1250) recommended it. ${ }^{171}$ At least two witnesses would be present in accordance with precepts in the Bible and old Anglo-Saxon law. ${ }^{172}$ Again, in post Conquest times, the witnesses did not subscribe their signature (i.e. attest). However, their names were recorded in the charter, as Blackstone noted:

They registered in the deed the persons who attended as witnesses, which was formerly done without their signing their names (that not being always in their power) but they only heard the deed read; and then the clerk or scribe added their names, in a sort of memorandum; thus, hiis testibus, Johanne Moore, Jacobo Smith, et aliis ad hanc rem convocatis [these being witnesses, John Moore, Jacob Smith and other witnesses being present at this matter]. ${ }^{173}$

This clause - often, called an attestation clause - was not the same as our modern one since the witnesses did not sign as such. In conclusion, in early times - including with deeds - legal documents were witnessed. However, the witnesses did not sign (attest) and witnessing was not a common law requirement. That is, it did not invalidate the transaction (including a deed) if lacking, although it was almost invariable in practice. In the time of Henry VIII (1509-47), the practice of signing had revived. Thus, the hiis testibus ('in witness whereof') clause was discontinued and witnesses attested, by signing as such on the legal document (invariably, a deed). ${ }^{174}$ Although this new practice prevailed, a deed still did not require witnessing (or attestation) to be valid as Goodard's Case (1584) noted. ${ }^{175}$ The Statute of Frauds 1677, s 5 required a will to be attested but not deeds or other legal documents - including commercial paper such as bills of exchange (including cheques), promissory notes and bonds (in early times called obligations) etc. ${ }^{176}$

\footnotetext{
${ }^{170}$ McBain Deeds, n 1, pt 1, pp 20 \& 31. Bracton (c. 1250) recommended witnesses and a sealing clause ('in witness thereof'). However, this was not a pre-requisite.

${ }^{171}$ Bracton, n 5, vol 2, p 119.'Witnesses ought to be called and let everything be done in their presence with due ceremony, that they may verify what was done if required to do so, and their names included in the charter. If they are not present at the making of the charter it is sufficient if it is afterwards read and approved in their presence, both donor and donee being present...and better still if all is done in a public place, as in the county or hundred court, so that if the gift is denied it may more readily be proved.' See also McBain Deeds, $\mathrm{n} 1$, pt 1 , $\mathrm{p} 21$.

${ }^{172}$ See n 103.

${ }^{173}$ Blackstone, n 13, vol 2, p 307. See also McBain Deeds, n 1, p 21.

${ }^{174}$ Coke, n 36, vol 1, s 1 (Co Litt 6(a)) 'And lastly, antiquity did add hiis testibus in the continent [body] of the deed after the in cuius rei testimonium, written with the same hand that the deed was, which witnesses were called the deed read, and then their names entered.... which clause of hiis testibus...continued until the reign of H 8 [Henry VIII, 1509-47] but now is wholly omitted.' See also Blackstone, n 13, vol 2, p 308. Henoted that the reign of Henry VIII was the era of discontinuing hiis testibus clause in deeds 'learning being then revived, and the faculty of writing more general; and therefore ever since that time the witnesses have subscribed their attestation, either at the bottom, or on the back, of the deed.' See also McBain Deeds, n 1, pt 1, p 40.

${ }^{175} 2$ Co Rep 4b at 5a (76 ER 396). "There are but three things of the essence and substance of a deed, that is to say, writing in paper or parchment, sealing and delivery, and if it hath these three, although it wanted, in cuius rei testimonium sigillum suum apposuit, [in witness whereof he put his seal] yet the deed is sufficient.' See also McBain Deeds, n 1, pt 1, pp 23-4.

${ }^{176}$ McBain Deeds, n 1, pt 1, p 24. For Scotland, see Ars Notariatus, n 1, p 50.
} 


\section{(b) $\underline{\text { Conclusion }}$}

Prior to 1677, witnessing (or attesting) a legal document was not a legal requirement at common law. The Statute of Frauds 1677 required wills to be attested. However, it did not require any legal document to be witnessed. In 1989, deeds were required to be attested in the case of individuals (this is also a requirement in the case of a power of attorney if the donor is an individual). If deeds, specialties and the seal are abolished, then, it should be clarified that any common law requirement to witness is abolished (simply, confirming that there is, actually, no such requirement, for the sake of good order). Further, any requirement to witness pursuant to any legislation, should be repealed. The only legal document that should have a mandatory requirement to be witnessed should be a will - if that. ${ }^{177}$ The reason for this, is that an otherwise perfectly valid legal document should not be invalidated simply by reason of it not being witnessed; this is draconian. Further, in practice, legal documents will, undoubtedly, continue to be witnessed (and attested). Thus, little will change.

In conclusion, no legal document should be compulsorily required to be witnessed - whether as a matter of common law or legislation. Witnessing should remain optional, with the possible exception of a will.

\section{OATHS \& DECLARATIONS}

An oath is a formality. So too, is a legal declaration. Indeed, the oath - even prior to the seal - was the means by which a person, in ancient times, declared himself to be bound. ${ }^{178}$ A Formalities Act should consolidate the following: (a) Oaths Act 1775: (b) Statutory Declarations Act 1835; (c) Promissory Oaths Act 1868; (d) Promissory Oaths Act 1871; (e) Commissioners for Oaths Act 1889; (f) Commissioners for Oaths Act 1891; (g) Evidence and Powers of Attorney Act 1943. As well as consolidation, these sections (there are few) should be modernised, see Appendix A. Indeed, one would suggest that it is essential that such material be placed in a Formalities Act in order to modernise and consolidate all formalities, instead of them being 'all over the shop' as at present.

\section{WRITING}

In Anglo-Saxon times as well as in medieval England, the word - and not the written word - predominated, since most of the population could not read or write. Thus, even though deeds required writing, the execution of most commercial transactions in markets and fairs would have been effected by a handshake, a drink to seal the bargain or another form of token, including the payment of money. ${ }^{179}$

- The result was that English common law did not require legal documents to be in writing, apart from a deed which had to be in writing (on parchment or paper), sealed and delivered. Even a will could be oral;

- This continues, in part, until today. Legal transactions such as a sale or an exchange (barter) or a gift (including a donatio mortis causa) do not have to be in writing in order to be valid. Nor does a pledge or a mortgage have to be in writing at common law, although they (invariably) are, not least since mortgages are usually registered.

This leaves uncertain what the common law (as opposed to legislation) stipulates must be in writing in order for the act to be legally valid. It is asserted that it would be useful to all lawyers (and laymen) to clarify this - as well as to remove the statutory anomaly as to a guarantee. This is required to be (or evidenced) in writing by the Statute of Frauds 1677, s 4 - whereas an indemnity may be oral. These matters are now considered, the common law reference being to 'instruments under hand', that is legal documents which are signed, as opposed to being sealed.

\section{(a) Common Law Requirement}

It is difficult to find any compulsory requirements for instruments under hand (excluding deeds which have always required writing) to be in writing by the common law - as opposed to legislation. Halsbury notes the following:

- Appointments of Property and to Offices. Halsbury notes that such are either appointments of: (a) property; or of (b) persons to offices (or other positions); or of (c) trustees or agents. Also, that: (a) were frequently authorised to be made under hand (as well as by deed or will). ${ }^{180}$ And, that the

\footnotetext{
${ }^{177}$ The Law Commission is, presently, looking at the modernization of wills.

${ }^{178}$ McBain Consideration, $\mathrm{n} 1$, pt 1, pp 14-5.

${ }^{179}$ Ibid, pt 1, pp 12-5.

${ }^{180}$ Halsbury, n 1, vol 32, para 346 cited (para 380, n 4) Brodrick v Brown (1855) $1 \mathrm{~K} \& \mathrm{~J} 328$. This case (dealing with a will) did not indicate whether the common law compulsorily required writing.
} 
appointment of a new trustee may (usually) be under hand but must, for certain purposes, be by deed. ${ }^{181}$ Further, that the appointment of an agent sometimes has to be in writing. ${ }^{182}$ Halsbury also cites statutory instances where writing is required; ${ }^{183}$

- Declarations of Trust \& Assignments. Halsbury noted that legislation required that all declarations of trust respecting land (or any interest in the same) had to be evidenced in writing. ${ }^{184}$ It also noted that assignments of various things had to be in writing, such as:

(a) equitable interests in land (whether created by the assignment or previously subsisting);

(b) other equitable interests (or trusts) subsisting at the time of the assignment;

(c) an equitable mortgage (save, perhaps, mortgages by deposit of title deeds assigned for value);

(d) shares and debentures (other than bearer securities);

(e) government stocks;

(f) copyrights;

(g) patents;

(h) registered trade marks;

(i) statutory legal assignments of life (or marine) insurance policies;

(j) legal assignments of legal choses or things in action.

In respect of these, Halsbury referred to legislation, save for (b);

- Assent on Death, Acknowledgments of Title or of Debts. Halsbury refers to legislation in respect of such matters; ${ }^{185}$ So too, in respect of Notices in Writing, Appointment of a Guardian, Other Matters required to be in Writing. ${ }^{186}$

Given the uncertainty as to the common law position - as well as the fact that there are so few instances ${ }^{187}$ and the fact that the caselaw is so old - a Formalities Act should provide that any common law requirement that any legal act is obliged to be in writing, be abolished. In practice, this will change nothing since even those instances cited above are, invariably, in writing (or evidenced in writing).

\section{(b) Guarantees $v$ Indemnities}

Indemnities do not have to be in writing. However, anomalously, guarantees do - in accordance with the terms of the elderly Statute of Frauds 1677, section 4. This anomaly has been considered in a long article. ${ }^{188}$ Thus, any analysis will not be dealt with here. However, the retention of such an anomaly tends to bring English law into disrepute since such is a positive invitation to a party to a guarantee against whom section 4 is pleaded, to consider perjuring themselves by swearing that what was once a taken to be a guarantee should now be interpreted by a court as an indemnity.

In conclusion, any common law requirement for a legal act to be in writing should be abolished. So too, the Statute of Frauds 1677, section 4.

\section{CONCLUSION}

We live in an age where the signature is 'king'. And, where the electronic signature is developing rapidly. Also, where legal formalism has long given way to commercial reality and to a recognition that formal requirements should not be allowed to void otherwise legally valid transactions, unless there are exceedingly good reasons for this. Further, as with Mansfield CJ (1756-88), today's judges are well aware that the law should assist

\footnotetext{
${ }^{181}$ Ibid, para 346 citing para 218.

${ }^{182}$ Ibid. Halsbury cited Coles $v$ Trecothick (1804) 9 Ves 234, 250. This case (dealing with a purchase of debts and the Statute of Frauds 1677) did not indicate whether the common law compulsorily required writing.

${ }^{183}$ viz. Representation of the People Act $2000 \mathrm{~s} \mathrm{12}$, sch 4 (application for the appointment of a proxy to vote at elections); Government Stock Regulations SI 2004/1611, pt 3 (instruments in writing with regard to the registration, certification and transfer of British government stock).

${ }^{184}$ Halsbury, n 1, vol 32, para 347. Cf. a trust of personal estate did not have to be in writing.

${ }^{185}$ Ibid, paras $349 \& 350$

${ }^{186}$ Ibid, paras 352-4. The Statute of Frauds Amendment Act 1828, s 6 referred to in para 354 has been repealed.

${ }^{187}$ Those cited above refer to:(a) writing for an appointment to property; and (b) possibly, other equitable interests existing at the time of the assignment.

${ }^{188}$ GS McBain, Abolishing the Statute of Frauds 1677, Section 4 [2010] Journal of Business Law, Issue 5, pp 420-3.
} 
commerce and economic development and not be a via crucis. What should be done, therefore ? The Law Commission (or other experts) should review the law on Deeds, Specialties and Seals (together, since all refer to seals) and issue a report. Thereafter, in a separate report, the Law Commission (or other experts) should consider other formalities for documents (viz. notarisation, attestation, witnessing and the requirement of writing). What should be the outcome? The following is suggested as providing the greatest assistance for the development of law and commerce - as well as for ensuring certainty, something the Law Commission has noted the need for: ${ }^{189}$

- Deeds \& Specialties. These legal concepts should be abolished. The benefits of a deed in respect of: (a) an extended limitation period (12 years); (b) consideration; and (c) privity, should apply to any legal document. Mansfield CJ proposed this for consideration long ago (Pillans $v$ Mierop, 1765) as did Holdsworth in modern times. And, privity now applies generally to contracts pursuant to legislation (Contracts (Rights of Third Parties) Act 1999);

- Sealing. This should be abolished. ${ }^{190}$ As it is, individuals no longer seal. However, now, nor do most corporations sole, partnerships or corporations aggregate, in practice. Sealing should be abolished and all should now sign. The signature of one designated person (or, at most, two) should be sufficient;

- Notarisation. Any requirement to notarise any writing at common law should be abolished. The requirement to note, and protest, foreign bills in the BEA 1882 (including protest for better security, as well as acceptance (or payment) by way of honour supra protest) should be abolished;

- $\quad$ Attestation. Any requirement to attest at common law should be abolished and any legislative requirement, repealed. Attestation is too onerous. It was never, in the past, required for a deed (which only required sealing on parchment or paper and delivery). Further, attestation does not prevent or inhibit forgery or fraud per se. Abolishing a compulsory requirement to attest at common law or in legislation will not prevent persons attesting, in practice. However, a failure to do will not invalidate the legal document;

- Witnessing. Any requirement to witness at common law should be abolished and any legislative requirement, repealed - with the possible exception of a will. Witnessing was never required for a deed in the past and - as with attestation - it does not prevent or inhibit forgery or fraud per se. Abolishing a compulsory requirement to attest at common law or in legislation will not prevent persons doing this in practice. However, a failure to do will not, then, invalidate the legal document;

- Writing. Any requirement of writing at common law should be abolished. The requirement that a guarantee (or any note or memo thereof) must be in writing and signed by the guarantor or his agent), as contained in the Statute of Frauds 1677, s 4, should be repealed;

- Amending Legislation. If deeds, specialties and seals are abolished, references to them in legislation should be removed. Also, terms now obsolete such as to 'indentures' and 'deed polls' as well as to 'simple contracts' - which reference will have no meaning if deeds are abolished. ${ }^{191}$ A composite removal of all references would seem apposite, see Appendix $\mathbf{A}$.

All the above should be contained in a Formalities Act, so that such matters are gathered together in one place (including material on the great and privy seal as well as in respect of oaths). If this was done, it would clear out the legal detritus (and anomalies) of the centuries and make the law on the formal requirements for the execution of documents fit for the electronic age.

\footnotetext{
${ }^{189}$ McBain Deeds, $\mathrm{n} 1$, pt 1, p 15 citing the Law Commission 'It is a matter of everyday practical importance that the way in which a company or other corporation executes a document that will bind it should be well-known, simple and rational...Any situation where those advising either party [to a deed or other legal document] are left in any uncertainty as to what is a valid method of execution, and so whether a document will be effective, seems to us to be deeply unsatisfactory.' See also Law Commission: The Execution of Deeds and Documents by or on behalf of Bodies Corporate. Consultation Paper (1996), no 143, paras 1.1 \& 1.6. See also McBain Deeds, n 1, pt 2, p 13. Beale $v$ Thompson (1803) 3 B \& P 421 per Chambre J 'The great object of the law is to encourage commerce'. Medcalf v Hall (1782) 3 Doug 113 (99 ER 566), p 113 per Mansfield CJ 'Nothing is more mischevious than uncertainty in mercantile law...Convenience is the basis of mercantile law.'

${ }^{190}$ This would include the use of a corporate seal for foreign purposes (see now Companies Act 2006, s 49) since retention of this as an exception simply preserves the nature of a seal and the concept of a deed. It may be noted that companies in most European countries have no seal and this has caused (it seems) no problems. See McBain Deeds, n 1, pt 2, pp $12 \& 25$.

${ }^{191}$ McBain Deeds, n 1, pt 2, pp 14 \& 28. References to 'instrument under hand' and 'instrument in writing' would be, better, altered to refer to writing.
} 


\section{APPENDIX A - FORMALITIES ACT}

\section{Deeds, Specialties, Sealing}

(1) The following are abolished, the:

(a) legal concept of a deed;

(b) legal concept of a specialty;

(c) sealing of any legal document.

(2) Any reference to a deed, specialty or sealed legal document (instrument) ${ }^{192}$ in any:

(a) legislation; ${ }^{193}$ or

(b) articles of incorporation, articles of any charter or other constitutional document,

shall now be construed as a reference to a legal document as signed.

(3) The following benefits of a deed shall now apply to any legal document, to the extent the same applied to a deed:

(a) consideration;

(b) privity.

\section{Valid Execution of a Legal Document}

(1) Subject to sections 3 and 4, notwithstanding:

(a) any legislation; or

(b) articles of incorporation, articles of any charter or other constitutional document,

a legal document is validly executed in the case of :

(c) an individual, if signed by the same; ${ }^{194}$

(d) a corporation sole, if signed by the same;

(e) a corporation aggregate, if signed by a designated person;

(f) a foreign corporation aggregate, if executed in any manner permitted by its foreign law (or, if no provision is made, if signed by a designated person);

(g) a general partnership, if signed by each partner (or his attorney);

(h) a limited liability partnership, if signed by a designated person;

(i) the county palatine of Lancaster or the Duchy of Lancaster, if signed by the Duke of Lancaster;

(j) the Duchy of Cornwall, if signed by the Duke of Cornwall.

(2) 'designated person' means [a statutory instrument should set out who, in the case of corporations aggregate and partnerships, may execute a legal document on behalf of the same. Also, specimen clauses].

\section{Great Seal and Privy Seal ${ }^{195}$}

(1) A warrant under Her Majesty's Royal Sign Manual, countersigned by the Lord Chancellor (or such other person as Her Majesty shall appoint in the case of his incapacity or absence) ${ }^{196}$ or by one of Her Majesty's Principal Secretaries of State shall be a necessary and sufficient authority for passing any instrument under the Great Seal of the United Kingdom, according to the tenor of such warrant; ${ }^{197}$

(2) The Lord Chancellor may from time to time make, revoke and vary, regulations respecting the passing of instruments under the Great Seal (and respecting the warrants for that purpose) and the preparation of such shall be

\footnotetext{
${ }^{192}$ In older times, the word 'instrument' was a general reference to a writing intended to be legally binding. See also $\mathrm{n} 2$.

193 This includes all general, local and private legislation as well as statutory instruments (and can be defined as such).

194 This would include Her Majesty, if signing in a personal capacity (the privy signet have been abolished).

195 This wording is designed to modernize wording in the: (a) Great Seal Act 1688: (b) Great Seal (Offices) Act 1874; (c) Great Seal Act 1884; (d) Crown Office Act 1877, repealing all of (a)-c). However, it may also be worth repealing (d) and putting the other sections of that Act into this Act, for the sake of completeness.

${ }^{196}$ This is intended to modernize the Great Seal Act 1688 since the office of commissioner is now redundant.

197 This is intended to modernize the Great Seal (Offices) Act 1874, s 2(1). Section 2(3) of that Act would appear to be unnecessary.
} 
prepared by the Clerk of the Crown in Chancery (whose appointment and fees such regulations may also provide for); ${ }^{198}$

(3) A Committee of Her Majesty's Most Honourable Privy Council, consisting of the Lord Chancellor, the Lord Privy Seal and one of Her Majesty's Principal Secretaries of State (acting in case of difference, according to the opinion of any two of them) may from time to time:

(a) direct impressions with the same device as the Great Seal and of the Privy Seal to be taken in such manner and of such size(s) as they may from time to time prescribe, on embossed paper, wax, wafer, or any other material. Any such impressions (hereafter, called a Wafer Great Seal and a Wafer Privy Seal) shall be in the same custody as the seals of which they are impressions. And, when attached to or embossed on any document required to be or usually authenticated by (or passed under) the Great Seal or Privy Seal, shall confer on that document the same validity in all respects as if the document had been authenticated by (or passed under) the Great Seal or Privy Seal; ${ }^{199}$

(b) by order, make, revoke, add to, or alter rules prescribing the documents to which the Wafer Great Seal and the Wafer Privy Seal are to be attached; provided that it shall not be necessary to the validity of any document to (or on which) a Wafer Great Seal or Wafer Privy Seal is attached (or embossed) to prove that the attachment (or embossing) was authorised and no evidence to the contrary shall be received. Any rule purporting to be made pursuant to this section (b) shall be laid before both Houses of Parliament. ${ }^{200}$

\section{4. $\underline{\text { Royal Sign Manual }}^{201}$}

(1) Execution by Her Majesty under the Royal Sign Manual is valid on the subscription of Her signature save where legislation requires otherwise.

\section{Power of Attorney}

[Wording should consolidate and modernise the Powers of Attorney Act 1971, the Powers of Attorney (Northern Ireland) Act 1971 and the Evidence and Powers of Attorney Act 1940, removing spent sections. As for execution, this section should provide that a power of attorney shall be executed by the donor in accordance with section 2.$]$

\section{Notarisation}

(1) Any requirement to notarise a legal document at common law is abolished.

\section{Attestation and Witnessing}

(1) Subject to section 6(2), any requirement to attest, or to witness, a legal document:

(a) at common law; or in any

(b) legislation; or

(c) articles of incorporation; articles of any charter; or other constitutional document,

is abolished.

(2) Section 6(1) shall not apply to the Wills Act [2019].

\section{Writing}

(1) Any requirement at common law that a legal document must be in writing to be valid is abolished.

\section{Contracts for the Sale of Land etc. to be made by signed writing ${ }^{202}$}

(1) A contract for the sale or other disposition of an interest in land can only be made in writing and only by incorporating all the terms which the parties have expressly agreed in one document (or, where contracts are exchanged, in each);

\footnotetext{
${ }^{198}$ This is intended to modernize the Great Seal Act 1884, s 2(2). The latter wording is intended to modernize the Great Seal (Offices) Act 1874 , ss $8 \& 9$ (the other sections are spent).

199 This is intended to modernise the Crown Office Act 1877, s 4.

${ }^{200}$ This is intended to modernize the Crown Office Act 1877, s 5. It is suggested that s 5(3)(b) is spent.

201 This wording is designed to provide for the current legal position in respect of the Sign Manual.

${ }^{202}$ This is intended to modernize the Law of Property (Miscellaneous Provisions) Act 1989, s 2. See also Halsbury, n 1, vol 32, para 345.
} 
(2) The terms may be incorporated in a document either by being set out in it or by reference to some other document;

(3) The document incorporating the terms (or, where contracts are exchanged, one of the documents incorporating them, but not necessarily the same one) must be signed by (or on behalf of) each party to the contract;

(4) Where a contract for the sale or other disposition of an interest in land satisfies the conditions of this section by reason only of the rectification of one or more documents in pursuance of an order of a court, the contract shall come into being, or be deemed to have come into being, at such time as may be specified in the order;

(5) This section does not apply in relation to - (a) a contract to grant such a lease as is mentioned in section 54(2) of the Law of Property Act 1925 (short leases); (b) a contract made in the course of a public auction; or (c) a contract regulated under the Financial Services and Markets Act 2000, other than a regulated mortgage contract, a regulated home reversion plan, a regulated home purchase plan or a regulated sale and rent back agreement; and nothing in this section affects the creation or operation of resulting, implied or constructive trusts;

(6) In this section -'disposition' has the same meaning as in the Law of Property Act 1925; 'interest in land' means any estate, interest or charge in or over land or in or over the proceeds of sale of land; 'regulated mortgage contract', 'regulated home reversion plan', 'regulated home purchase plan' and 'regulated sale and rent back agreement' must be read with: (a) section 22 of the Financial Services and Markets Act 2000, (b) any relevant order under that section, and (c) Schedule 2 to that Act.

\section{Oaths \& Declarations}

[Wording should consolidate and modernise the: Oaths Act 1775, Statutory Declarations Act 1835, Promissory Oaths Act 1868, Promissory Oaths Act 1871, Commissioners for Oaths Acts 1889 \& 1891 and the Evidence and Powers of Attorney Act 1943].

\section{Interpretation}

(1) 'Legal document' means any writing intended to have legal effect.

\section{Repeals, Amendments, Short Title and Extent}

(1) The following are repealed:

(a) Statute of Frauds $1677 ;^{203}$

(b) Bills of Exchange Act 1882, sections 44(2), 51, 66, 67, 68, 93, 94:204

(c) Law of Property Act 1925, ss 52, 55, 56(2), 57, 74, 74A, 75;

(d) Corporate Bodies Contracts Act $1960 ;{ }^{206}$

(e) Law of Property (Miscellaneous Provisions) Act $1989 ;{ }^{207}$

(f) Limitation Act 1980, section $8 .^{208}$

(2) Any reference in any legislation to:

(a) an 'indenture' shall be replaced by one to a 'legal document';

(b) a 'deed poll' shall be replaced by one to a 'declaration';

(c) a 'simple contract' shall be replaced by one to a 'contract'.

(3) The Acts and Regulations referred to in Schedule 1 are amended as prescribed. [In particular, it would be useful to expressly amend the following (including any amendments to the same):

\footnotetext{
${ }^{203}$ The only extant section of this Act, s 4, deals with guarantees.

${ }^{204}$ These sections deal with the noting and protest of a bill, including protest for additional security and protest supra honor.

${ }^{205}$ Section 52 stipulates that conveyances must be by way of deed. Section 55 contains a saving as to s 52 . Section $56(2)$ provides that deeds do not need to be indented. Section 57 contains a description of a deed. Section 74 deals with the execution of instruments by (and on behalf of) companies. Section s 75 deals with rights of a purchaser in respect of execution.

206 This deals (ss 1 and 2) with execution by corporate bodies.

${ }^{207}$ Sections 3-6 of this Act are spent. Section 1 deals with deeds. Section 2 (contracts re land) should be re-stated in the Formalities Act (see s 9 above).

${ }^{208}$ This deals with the limitation period for specialties. It should be repealed and s 5 amended to cover any legal document, possibly, with an extended limitation period.
} 
(a) Companies Act 2006, ss 43-50; ${ }^{209}$

(b) Bills of Sale (1878) Act 1878 and the Bills of Sale Amendment Act 1882, sch;

(c) Land Registration Act 2002, ss 91(4) \& (5);

(d) Partnership Act 1890, s 6;

(e) Law of Property Act 1925, ss $101 \& 103$;

(f) The Companies (Unregistered Companies) Regulations SI 1985/680;

(g) Foreign Companies (Execution of Documents) Regulations SI 1984/950;

(h) Limited Liability Partnership Regulations SI 2001/1090, reg 4, sch 2.]

(4) This Act may be cited as the Formalities Act [20 ];

(5) This Act extends to Northern Ireland and in the case of sections [ ] it extends to Scotland.

\section{Copyright}

Copyright for this article is retained by the author(s), with first publication rights granted to the journal.

This is an open-access article distributed under the terms and conditions of the Creative Commons Attribution license (http://creativecommons.org/licenses/by/4.0/).

\footnotetext{
${ }^{209}$ Section 45 deals with the common seal. Section 43 deals with company contracts. Section 44 deals with the execution of documents. Section 46 deals with the execution of deeds. Section 47 deals with the execution of deeds or other documents by an attorney. Section 48 deals with the execution of documents by a company. Section 49 deals with the use of an official seal for use abroad. Section 50 deals with an official seal for share certificates.
} 